\title{
Optimal incorporation of multiple distributed generation units based on a new system maximum loadability computation approach and vortex searching algorithm
}

\author{
Y. Latreche ${ }^{1}$, H. R. E. H. Bouchekara ${ }^{2}$, M. S. Javaid ${ }^{3}$, M. M. Aman ${ }^{4}$, H. Mokhlis ${ }^{5}$, F. Kerrour ${ }^{6}$ \\ ${ }^{1,6}$ Modeling of Energy Renewable Devices and Nano-Metric (MoDERNa) Laboratory, University of Freres Mentouri \\ Constantine, Algeria \\ ${ }^{2,3}$ Department of Electrical Engineering, University of Hafr Al Batin, Saudi Arabia \\ ${ }^{4}$ Department of Electrical Engineering, NED University of Engineering and Technology, Pakistan \\ ${ }^{5}$ Department of Electrical Engineering, Faculty of Engineering, University Malaya, Malaysia
}

\section{Article Info}

Article history:

Received Dec 21, 2018

Revised Mar 6, 2019

Accepted May 12, 2019

\section{Keywords:}

Distributed generation

Maximum loadabilty

Power losses

Voltage profile

Vortex Searching algorithm

\begin{abstract}
In this paper, the optimal incorporation of distributed generation (OIDG) units for the maximization of the system's loadability is investigated (based on sizing and siting). To this end a new computational approach for computing maximum loadability of the system is developed. This approach has been compared with the classical one on different radial test systems (RTS) and is found to be faster and more accurate. The OIDG problem is formulated mathematically as an optimization problem with the objective function to maximize system's loadability, the imposed constraints are; voltage limits, thermal limits and DG penetration level. The optimization algorithm used is to solve the OIDG problem is the Vortex searching algorithm (VS). The tested radial distribution systems are the standard 33-bus and 69-bus systems. This paper also discusses some other interesting findings about VS algorithm.
\end{abstract}

Copyright () 2019 Institute of Advanced Engineering and Science. All rights reserved.

\section{Corresponding Author:}

Houssem Rafik El-Hana Bouchekara, Department of Electrical Engineering, University of Hafr Al Batin, Hafr Al Batin, 31991, Saudi Arabia. Email: bouchekara.houssem@gmail.com

\section{INTRODUCTION}

The word distributed generation (DG) is subjective in nature and its usage changes from region to another. For instance, in Anglo-American countries the term 'embedded generation' is used, however North American countries prefer it to call as 'dispersed generation', whereas Europe and parts of Asia use the terminology of 'decentralized generation' [1].

The definition of DG depends on the purpose like the size (MW), voltage level (kV), technology, cogeneration and others [1] defines. At present, council on large electric systems (CIGRE) considers DG to be not centrally planned, nor centrally dispatched and usually connected to the distribution network, smaller than 50-100 MW [2]. Various authors describe DG as a power generation source incorporated in the distribution network ranging from a few $\mathrm{kW}$ to a few tens of MW [1]. Some example of DG categories and ratings are micro-distributed generation $(\sim 1 \mathrm{~W}<5 \mathrm{~kW})$, small distributed generation $(5 \mathrm{~kW}<5 \mathrm{MW})$, medium distributed generation $(5 \mathrm{MW}<50 \mathrm{MW})$ and large distributed generation $50 \mathrm{MW}<300 \mathrm{MW}$.

A DG can be a traditional generator - based on combustion of diesel reciprocating generator and natural gas-turbine-and/or a non-traditional generator - relying on storage devices, fuel cells, or renewable energy source (such as wind turbine and photovoltaic) [1-3]. Advantages of DG over centralized generation are numerous including [4-7]: 
a. Power loss reduction

b. Voltage profile improvement

c. Enhanced system stability

d. Reduced pollutant emission

e. Relieved transmission and distribution lines.

However, there are several issues related with DG incorporation (i.e. placement and sizing) in the existing networks. The incorporation of DG alters the nature of network from passive one to that of active one, which has a significant impact in network operations. Non-optimized incorporation of DG can result in deterioration of the network performance. Therefore, the optimal incorporation of distributed generation (OIDG) is of paramount importance.

The problem of OIDG has been solved using analytical approaches. The initial work in DG placement was carried out by [8] based on the famous 2/3 rule of thumb. This work has been extended in [9] for three different kinds of loads. Later on, other analytical approaches have also been proposed to determine optimum DG placement as well as DG size. In [2], optimum size of DG is determined by using loss sensitivity based analytical equation, whereas, optimum DG location is determined by exact loss equation. Reference [10] covers the equivalent current injection based calculation of loss sensitivity factor injection by means of two matrixes: Bus-Injection to Branch-Current (BIBC) matrix and Branch-Current to Bus-Voltage (BCBV) matrix. A conventional iterative search algorithm is presented in [11] which deals with OIDG based on loss reduction and cost of DG size. Although this method is simple, it consumes a lot of time. Reference [12] ntroduces an improvement in analytical method for identification of optimal location for DG installation along with optimal power factor to achieve loss reduction in distribution networks.

Algorithms, based on multi-objectives optimization, have also been proposed for optimum DG placement and sizing. Methods based on Genetic Algorithm (GA) are proposed in [13-14] for optimizing DG placement and sizing, with various objective functions. Reference [15] has combined GA with Particle Swarm Optimization (PSO) for OIDG, solving multi-objective functions that include power losses, voltage regulation and voltage stability. GA-Fuzzy approach is used in [16] to optimize location of DG. Objective function also covers reduction in power system losses and system loading as well as the profit maximization for Distribution Companies. A dynamic programming approach is introduced in [17] to ascertain an optimized DG location that would ensure maximum profit. Reference [18] has used Ant Colony Search (ACS) Algorithm for reliability based OIDG location wise. In [19] PSO algorithm is implemented for optimum placement of DG while minimizing electricity cost for consumers. Reference [20] has used cuckoo search algorithm for optimum DG placement to obtain better voltage profile and also to decrease the power losses of the system.

Various other researchers have also considered OIDG as a multi-objective function optimization problem. Their fitness functions may include improved voltage regulation, reduction in power losses, and voltage stability [15]. Reference [13] has considered cost benefit due to reduction of power losses in case of DG placement in fitness function and ensure that voltage profile and reliability of the system is improved. It has been reported in [21] that incorporation of DGs gives rise to the loadability of overall distribution network.

In this paper, the optimal simultaneous incorporation of multiple DGs based on maximization of system loadability is investigated where the maximum loadability is determined using a new fast and accurate approach. The optimization algorithm used to solve the OIDG is the Vortex Searching algorithm (VS). This remainder of this paper is structured as follows. Section 2 presents the formulation of the OIDG problem. The optimization algorithm used in this paper, VS, is explained in section 3. Section 4 includes the discussion of main results obtained in this paper. Findings of this paper are concluded in section 5 .

\section{FORMULATION OF THE OIDG PROBLEM}

Explaining The primary purpose of OIDG problem is to determine the optimal placement and size of DG for improved system performance. The OIDG problem can be formulated as follows [22]:

$$
\begin{aligned}
& \text { Minimize } \quad f(\mathbf{x}) \\
& \text { Subject to } \quad g_{i}(\mathbf{x})=0 \quad i=1: k \\
& \text { and } \quad h_{j}(\mathbf{x}) \leq 0 \quad j=1: m \\
& \text { where } \quad \mathbf{x}=\left[x_{1}, x_{2}, \ldots, x_{n}\right]
\end{aligned}
$$


where:

$f(\mathbf{x})$ is the objective function.

$\mathbf{x}$ is the vector of design variables, $x_{i}$ is the ith design variable and $n$ represents the number of design variables.

$\mathrm{g}(\mathbf{x})$ denotes the set of equality constraints and $k$ is the number of equality constraints.

$\mathrm{h}(\mathbf{x})$ is the set of inequality constraints and $m$ is the number of inequality constraints.

\section{Design variables}

As previously mentioned, this paper aims to ascertain the optimal size and location of DGs to be inserted in the system. Therefore, the following design variables are considered.

Size

The size of DG means the amount of power generated by the DG unit. In following sections, the active power of DG, denoted by $P_{D G}$, is considered as a design variable and the reactive power of DG, $Q_{D G}$, is calculated using the following expression:

$\mathrm{Q}_{\mathrm{DG}}=\mathrm{P}_{\mathrm{DG}} \times \tan \left(\cos ^{-1}(\mathrm{PF})\right)$

The size of DG has to respect the following constraint:

$$
0 \leq \sum_{k=1}^{\mathrm{N}_{\mathrm{DG}}} \mathrm{P}_{\mathrm{DG} k} \leq \sum \mathrm{P}_{\mathrm{Load}}
$$

where: PF stands for power factor.

\section{Location}

Location of DG means the optimal bus to insert the DG unit. The location or position of DG has to respect the following constraint:

$$
2 \leq \mathrm{DG}_{\text {location }} \leq n b
$$

where: $n b$ is the number of buses.

Furthermore, if there are more than one of DG unit, the following constraint has to be respected also:

$$
\mathrm{DG}_{\text {location } 1} \neq \mathrm{DG}_{\text {location } 2} \neq \cdots \neq \mathrm{DG}_{\text {location } \mathrm{N}_{\mathrm{DG}}}
$$

\section{Power factor}

In some of the investigated cases of this paper, the PF of the DG unit is imposed and in some of them the PF is considered as a design variable and it has to be determined.

\section{Objective function}

Here, the main objective function is system maximum loadability.

\section{Maximum loadability}

Different definitions and different terminologies of loadability and maximum loadability have been reported in [23-28]. These definitions vary in terms of constraints, stability of system and the representation of loadability.

Maximum loadability or maximum loading margin is used to refer maximum power load that could load the system to the point of instability from the base load. Maximum loadability of the system indicates how much the system must be stressed in order to reach the instability. Voltage instability is considered a crucial parameter throughout this paper, thus the maximum loadability of the system can be defined as the maximum increase in power system load from the base load till the point where voltage collapses. Maximum loadability of the system represents the loading factor in multiple of base case load till the point of voltage collapse and represented with the variable $\lambda_{\max }$. The maximum loadability of the system can also be referred as or Voltage Stability Margin (VSM) or Voltage Stability Limit (VSL).

\section{Proposed approach}

In this paper, a new approach for calculating $\lambda_{\max }$ is proposed. This approach is much faster than the classical one proposed and implemented in [21]. The flowchart of the proposed approach is given in Figure 1. 


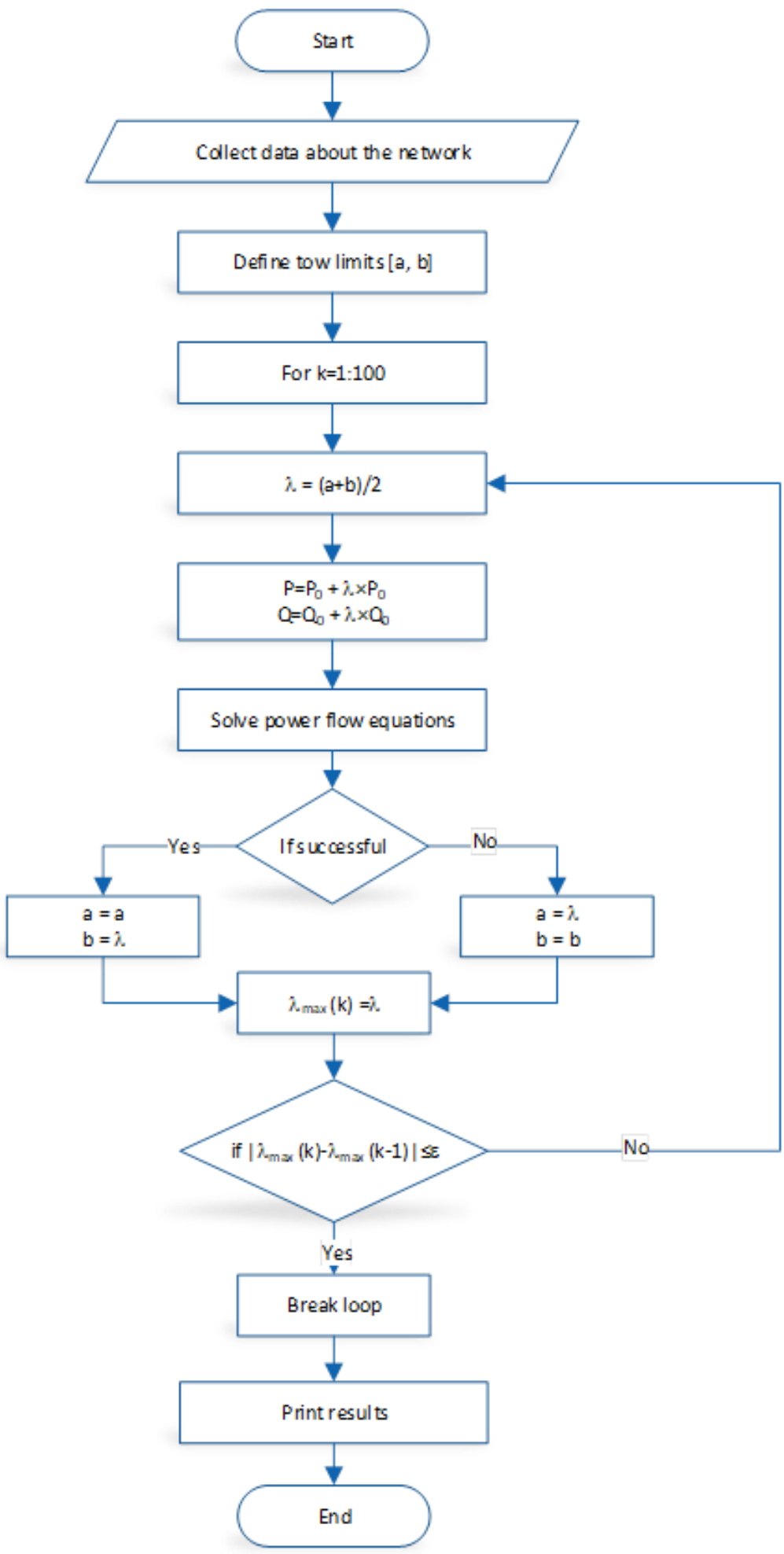

Figure 1. Flowchart for the calculation of $\lambda_{\max }$.

To find the maximum loadability i.e. $\lambda_{\max }$, on each bus, both active and reactive power are increased using the following:

$$
P=P_{0} \times \lambda
$$

$=Q_{0} \times \lambda$

Optimal incorporation of multiple distributed generation units based on a new system... (Y. Latreche) 
where: $P_{0}$ and $Q_{0}$ are the initial active and reactive powers of combined loads, respectively. Similarly, $P$ and $Q$ represent the new active and reactive powers (loads), respectively and $\lambda$ is the loading factor.

However, instead of keep increasing $\lambda$ using a smal step as in the classical approach [21], here we start from an initial interval $[\mathrm{a}, \mathrm{b}]$, then $\lambda$ is calculatd as the midpoint of this interval. After that, $\mathrm{P}$ and $\mathrm{Q}$ are increased using equations (9) and (10). The power flow equations are solved, if it is successful the new interval will be $[a, \lambda]$ otherwise the new interval will be $[\lambda, b]$. This process is continued until the interval [a, b] becomes smaller than a predefined tolerance $(\varepsilon)$.

\section{Comparative study}

In order to show the speed and efficiency of the proposed approach compared to the one proposed in [21], several tests have been achieved as shown in Table 1. In this table, the $\lambda_{\max }$ and the time taken to compute the $\lambda_{\max }$ are reported.

It can be noticed from Table 1 that, the $\lambda_{\max }$ is the same using both approaches for all cases, however, there is a huge time difference between both approaches. For instance for the 10-bus radial system the time has been reduced by $94.64 \%$, for the 69-bus radial system the time has been reduced by $99.14 \%$ and for the 118-bus radial system the time has been reduced by $99.07 \%$ using the proposed approach compared to the one proposed in [21].

Moreover, it is worth mentioning that, this time has been computed for one simulation, therefore, if this simulation is repeated a thousand times as when solving the OIDG problem the gain in time becomes extremely important.

Table 1. Comparison of the Proposed Approach with the Classical One

\begin{tabular}{lcccc}
\hline \multirow{2}{*}{ Test system } & \multicolumn{2}{c}{ Classical approach } & \multicolumn{2}{c}{ Proposed approach } \\
\cline { 2 - 5 } & $\lambda_{\max }$ & Time (s) & $\lambda_{\max }$ & Time (s) \\
\hline 10-bus radial system [29] & 2.064 & 1.698 & 2.063 & 0.091 \\
16-bus radial system [21] & 7.550 & 7.852 & 7.549 & 0.110 \\
33-bus radial system [30] & 3.407 & 9.648 & 3.406 & 0.125 \\
69-bus radial system [31] & 3.210 & 28.813 & 3.210 & 0.245 \\
85-bus radial system [32] & 2.599 & 31.958 & 2.599 & 0.326 \\
118-bus radial system [33] & 2.465 & 46.933 & 2.464 & 0.438 \\
\hline
\end{tabular}

\section{Constraints}

For OIDG, both equality and inequality constraints are present in problem formulation.

Equality constraints

$$
\begin{aligned}
& P_{g i}=P_{i}+V_{i} \sum_{j=1}^{n b} \mathrm{~V}_{j} Y_{i j} \cos \left(\delta_{i}-\delta_{j}-\theta_{i j}\right) \\
& Q_{g i}=Q_{i}+V_{i} \sum_{j=1}^{n b} V_{j} Y_{i j} \sin \left(\delta_{i}-\delta_{j}-\theta_{i j}\right)
\end{aligned}
$$

where;

$n_{i}=1 ; 2 ; \ldots ; n_{n}$

$P_{g i}$ is generator active power output at bus $n_{i}$

$Q_{g i}$ is generator reactive power output at bus $n_{i}$

$P i$ is active power demand at bus $n i$

$Q i$ is reactive power demand at bus $n_{i}$

$V_{i}$ is voltage of bus $n i ; \delta_{i}$ is phase voltage angle at bus $n i$;

$N=n i_{-}{ }_{1}$ is total number of branches in the given radial distribution system.

$\mathrm{N}$ represents total number of buses in given radial distribution system

\section{Inequality constraints \\ Voltage limits}

The nodal voltages must be constrained between their minimum and maximum limits. Therefore, voltage limits constraint can be formulated as follows:

$$
V_{\min } \leq V_{i} \leq V_{\max }
$$

\section{Thermal limit}

Power flow through any distribution feeder must comply with the thermal capacity of the line. Therefore, the thermal limit constraints can be formulated as follows: 
$\left|S_{i}\right| \leq\left|S_{i}^{\max }\right|, i=1, \ldots, N$

where: $S_{i}$ is the apparent power at branch $i$ and $S_{i}^{\max }$ is the maximum apparent power at branch $i$.

\section{Maximum capacity}

The maximum capacity of DGs that can be installed in the network is restricted by DG penetration level $\left(D G_{P L}\right)$. Therefore, there is a capacity constraint at unity power factor of DG generating power that is given by following expression:

$$
P_{D G_{i}} \leq \frac{\left(D G_{P L} \times P_{\text {load }}\right)}{N_{D G}}
$$
modified as:

If both active and reactive powers are being generated by DG, then the precedent equation can be

$$
S_{D G_{i}} \leq \frac{\left(D G_{P L} \times S_{\text {load }}\right)}{N_{D G}}
$$

where $N_{D G}$ is the total number of DG units incorporated in the power system; $D G_{P L}$ represents maximum penetration level as a percentage of peak load of the system; $P_{\text {load }}$ and $S_{\text {load }}$ are denoting total active power load and total apparent power load of the system, respectively.

\section{Constraints handling procedure}

It is worth to mention that the inequality constraints are taken into account using the penalty method. In this method a penalty term is added to the primary objective function which consists of multiplying a penalty parameter by a penalty factor. The penalty parameter is a measure of how much the constraints are violated, if there is no violation this parameter is null. This method has been implemented and used by the VS algorithm to handle inequality constraints.

\section{Evaluation indices}

The evaluation of the OIDG on system performance is performed using the following indices where the subscript (0) represents values before the incorporation of DG and the subscript DG represents the values calculated after the incorporation of DG [21].

\section{Active losses reduction index}

The Active Losses Reduction (ALR) index is be given by:

$$
\text { ALR }=\frac{\mathrm{P}_{\text {Losses }_{0}}-\mathrm{P}_{\text {Losses }_{\mathrm{DG}}}}{\mathrm{P}_{\mathrm{Losses}_{0}}} \%
$$

where: The active power losses are set as follows:

$$
P_{\text {Losses }}=\sum_{k=1}^{N} R_{k}\left|I_{k}^{2}\right|
$$

where: $R_{k}$ is the resistance of branch $\mathrm{k}, I_{k}$ represents the current passing through branch $k$ and $N$ denotes the total number of branches.

\section{Reactive losses reduction index}

The Reactive Losses Reduction (RLR) index is given by:

$$
\mathrm{RLR}=\frac{\mathrm{Q}_{\text {Losses }_{0}}-\mathrm{Q}_{\text {Losses }} \mathrm{DG}}{\mathrm{Q}_{\text {Losses }_{0}}} \%
$$

\section{System loadability improvement index}

The system loadability improvement (SLI) index is given by:

$$
\mathrm{SLI}=\frac{\lambda_{\max _{\mathrm{DG}}-\lambda_{\max _{0}}}}{\lambda_{\max _{0}}} \%
$$




\section{Voltage profile improvement index}

The voltage profile improvement (VPI) index is given by:

$\mathrm{VPI}=\frac{\mathrm{VP}_{0}-\mathrm{VP}_{\mathrm{DG}}}{\mathrm{VP}_{0}} \%$

Where the voltage profile is defined as follows:

$\mathrm{VP}=\sum_{i=1}^{n_{b}}\left(V_{i}-V_{\text {rated }}\right)^{2}$

Where $V_{\text {rated }}$ is the rated voltage (taken as 1 p.u. in this paper).

\section{Voltage stability enhancement index}

The voltage stability enhancement index (VSIM) is as follows:

$\mathrm{VSIM}=\frac{\mathrm{VSI}_{\mathrm{DG}}-\mathrm{VSI}_{0}}{\mathrm{VSI}_{0}} \%$

and voltage stability index (VSI) will be expressed as [34]:

$\mathrm{VSI}=\min \left(\frac{1}{\operatorname{SI}\left(n_{i}\right)}\right) \quad n_{i}=2,3, \ldots, n b$

where SI of node $n_{i}$ is given by:

$\operatorname{SI}\left(\mathrm{n}_{\mathrm{i}}\right)=\left|V_{m i}\right|^{4}-4\left[P_{n i}\left(n_{i}\right) R_{n i}+Q_{n i}\left(n_{i}\right) X_{n i}\right]\left|V_{m i}\right|^{4}-4\left[P_{n i}\left(n_{i}\right) X_{n i}+Q_{n i}\left(n_{i}\right) R_{n i}\right]^{2}$

where $V_{m i}$ is the voltage of bus mi, $P_{n i}\left(n_{i}\right)$ is total real power load fed through bus ni, $Q_{n i}\left(n_{i}\right)$ is total reactive power load fed through bus ni, $R_{n i}$ is the resistance of branch I, $X_{n i}$ is the reactance of branch i.

\section{Number of buses violating voltage limit}

Number of buses violating voltage limit (NBVV), as indicated by its name, counts the numbers of busses where voltage limits (upper of lower limits) are not respected.

\section{OPTIMIZATION ALGORITHM}

The VS algorithm is a single-solution based metaheuristic that evolves to optimality using a generation and a replacement procedure. In the generation phase $\mathrm{N}$ candidate solutions are generated inside a radius around the best solution using a specified procedure and, in the replacement, phase a solution replaces the current best solution. This process is repeated until a termination criterion is met. It is reported in [35] that the VS has excellent performance for the optimization of mathematical functions. In this paper is used as the optimization algorithm for solving the OIDG problem.

\section{Algorithm description}

The flowchart of the VS algorithm is sketched in Figure 1. The main steps of the VS algorithm are explained below:

Step 1: in the initialisation phase, first the centre of the search space is selected as the first generated solution. Then, the initial radius is computed using the following expression:

$$
r_{0}=\sigma_{0} \frac{1}{\chi} \operatorname{gammaincinv}\left(\chi, a_{0}\right)
$$

where: gammaincinv is the inverse incomplete gamma function and $\sigma_{0}$ is the initial standard distribution calculated as follows:

$\sigma_{0}=\frac{\max (U B)-\min (L B)}{2}$

where: $U B$ is the upper bound of design variables, $L B$ is the lower bound of the design variables, $\chi$ is a random variable and $a_{0}$ is the shape parameter selected as 1 . 
After that, the best solution and fitness obtained so far referred to as $\mathrm{g}_{\text {best }}$ and $\mathrm{S}_{\text {best }}$, respectively are initialized with the first solution generated.

Step 2: in this step $\mathrm{N}$ candidate solutions (with $\mathrm{N}$ the size of solutions) are generated in the neighborhood of $\mathrm{g}_{\text {best }}$ using a Gaussian distribution where this neighborhood is characterized with the following radius:

$$
r=\sigma_{0} \frac{1}{\chi} \operatorname{gammaincinv}\left(\chi, a_{t}\right)
$$

where the shape parameter $a_{t}$ is decreased using the following expression:

$$
a_{t}=a_{0}-\frac{t}{\text { MaxItr }}
$$

where $t$ is iteration number and MaxItr is the maximum number of iterations.

It is worth to mention here that; this radius is of paramount importance in the convergence of the VS algorithm. For a given optimization problem, this radius is initialized with a high value (as in equation (1)) in order to promote the exploration phase in the first iterations and then it is decreased along with the number of iterations increases in order to promote the exploitation phase. It is reported in [35] that until a certain number of iterations is reached, the radius varies approximately linearly and then it decreases significantly. This behavior allows to have a good balance between exploration and exploitation phases.

Step 3: in the previous step some of the generated solutions may lay outside the search space, therefore they have to be brought back inside the search space using the following expression:

$$
S_{k}^{i}= \begin{cases}L B^{i}+\operatorname{rand} \cdot\left(U B^{i}-L B^{i}\right) & \text { if } S_{k}^{i}<L B^{i} \\ S_{k}^{i} & \text { if } L B^{i}<S_{k}^{i}<U B^{i} \\ L B^{i}+\operatorname{rand} \cdot\left(U B^{i}-L B^{i}\right) & \text { if } S_{k}^{i}>U B^{i}\end{cases}
$$

Step 4: in this step the generated solutions are evaluated in order to calculate their fitness's, the best solution among them is identified and noted as $g_{\text {best_New }}$ and $S_{\text {best_New. }}$ Then, if $S_{\text {best_New }}$ is found to be better than $S_{\text {best }}$, therefore $g_{\text {best }}$ and $S_{\text {best }}$ are updated.

Step 5: in this step the radius is updated using equation (28).

Step 6: finally, if the number of iterations exceeds MaxItr the process is stopped and $\mathrm{g}_{\text {best }}$ and $\mathrm{S}_{\text {best }}$ are displayed otherwise the process is repeated from Step 2.

The VS algorithm as it is proposed in is [35] does not handle discrete or integer design variables. Therefore, for the purpose of the OIDG problem we have added some modifications on the initial version of the VS algorithm to cope with this issue.

\section{RESULT AND DISCUSSION}

Provide In this paper, 62 case studies have been investigated using 2 test systems. More details about test systems and investigated cases are given in the following two subsections.

Test systems

In this paper, two test systems are considered: 33-bus and 69-bus RTS. The main characteristics of these systems are given in Table 2. Moreover, the single line diagrams of first and second test systems are shown in Figure 3 and Figure 4, respectively.

Table 2. The Main Characteristics of the Investigated Test Systems

\begin{tabular}{lcc}
\hline \multicolumn{1}{c}{ System } & 33-bus RTS & 69-bus RTS \\
\hline System Characteristics & Data is given in [30] & Data is given in [31] \\
Buses & 33 & 69 \\
Branches & 32 & 68 \\
Total active load (MW) & 3.7150 & 3.8021 \\
Total reactive load (Mvar) & 2.3000 & 2.6945 \\
Ploss (MW) & 0.2110 & 0.2250 \\
Qloss (Mvar) & 0.1430 & 0.1021 \\
$\lambda_{\max }$ & 3.4065 & 3.2102 \\
VSI & 1 & 1 \\
VP & 0.1338 & 0.0993 \\
$\mathrm{~V}^{\max }$ & 1.1 & 1.1 \\
$\mathrm{~V}^{\min }$ & 0.95 & 0.95 \\
$\mathrm{~S}^{\max }$ (MVA) & 5 & 5 \\
\hline
\end{tabular}




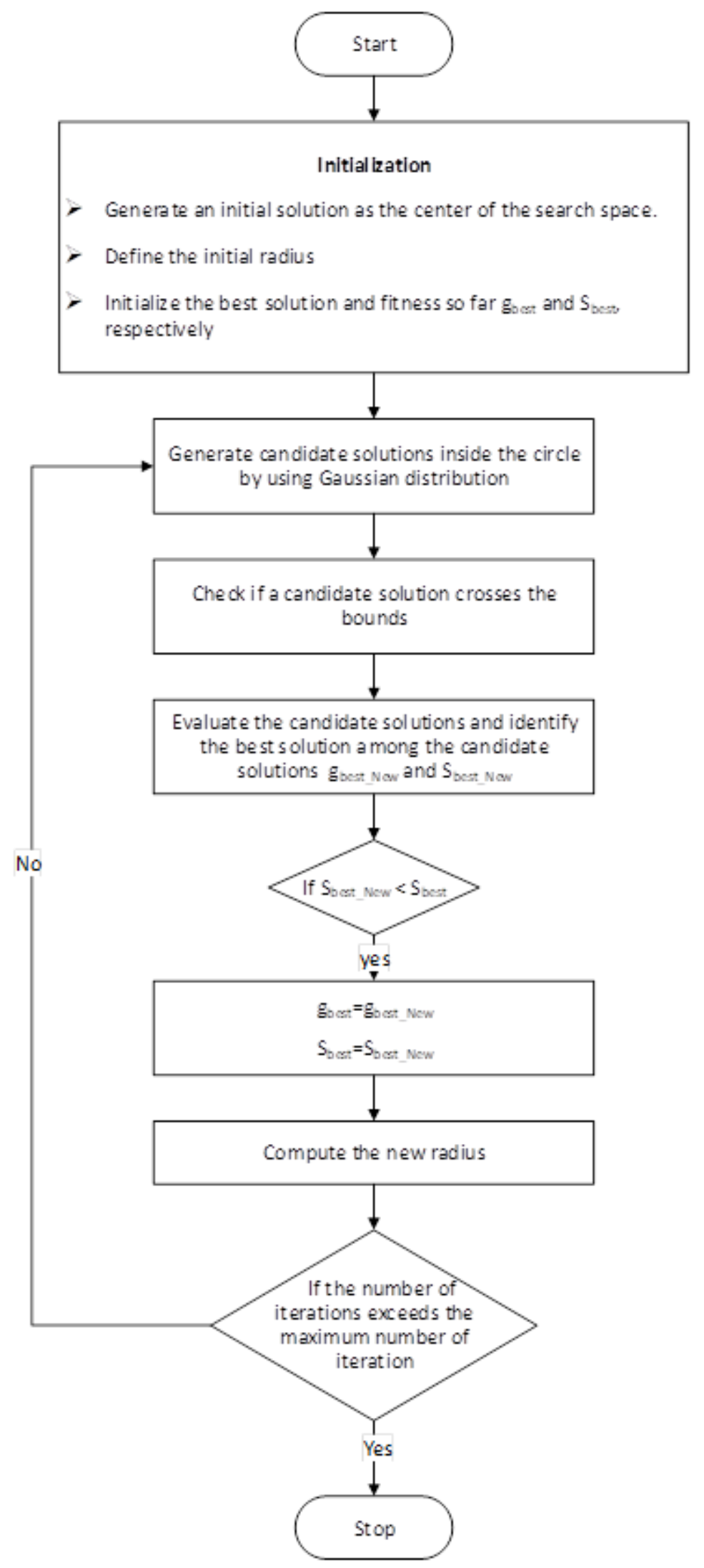

Figure 2. Flowchart of the vs algorithm 


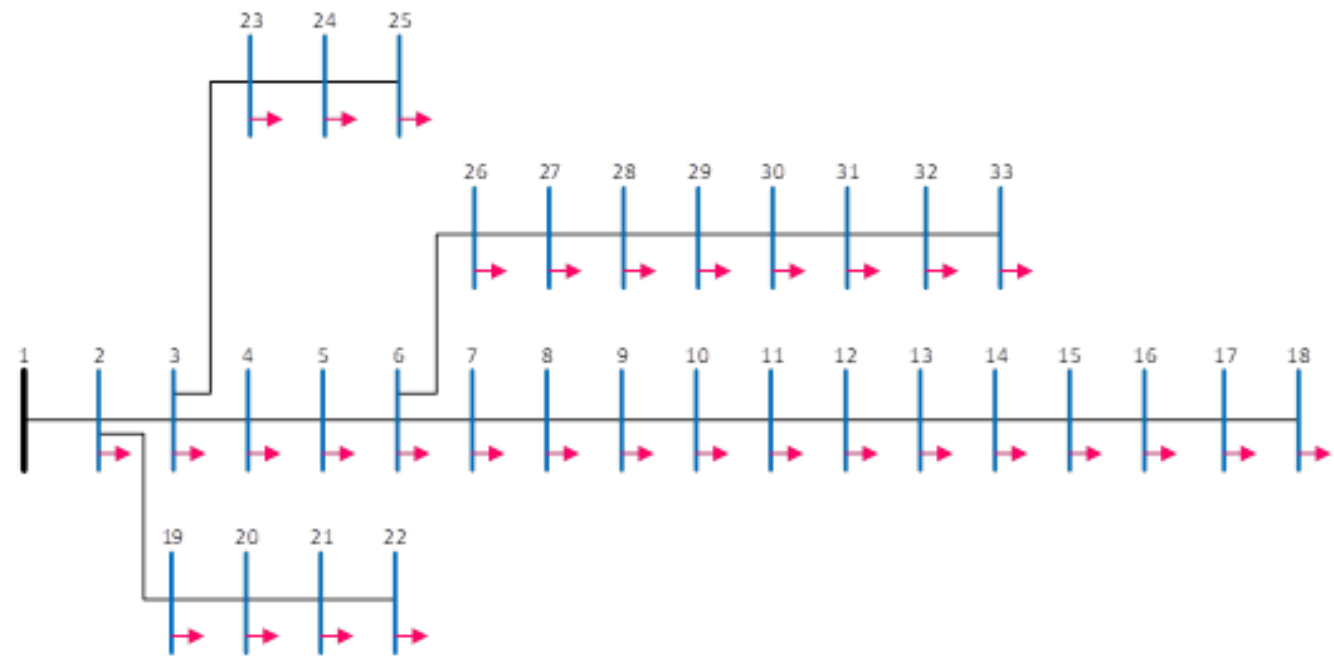

Figure 3. Single line diagram of the 33-bus RTS

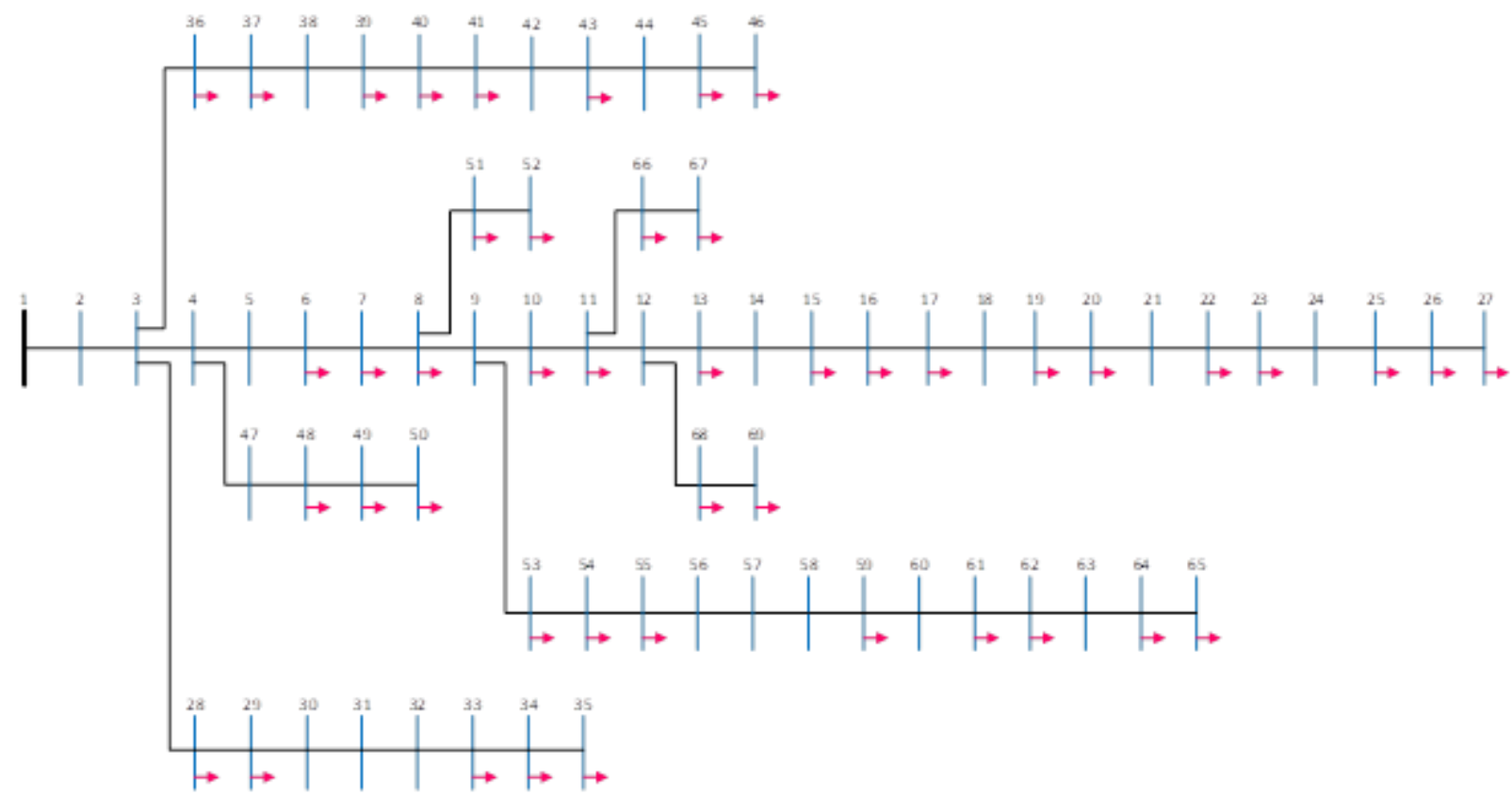

Figure 4. Single line diagram of the 69-bus RTS

\section{DG types}

Mainly, there are four different categories of DGs considered in literature as reported in [24].

Category 1: DG supplies active power only, e.g. solar system.

Category 2: DG supplies reactive power only, e.g. synchronous compensators.

Category 3: DG supplies active power but consumes reactive power, e.g. induction generator.

Category 4: DG supplies both active and reactive power e.g. synchronous generator.

In this work, where the PF is considered as unity the DG units are considered from Type 1 whilst when the PF is considered as a design variable the DG units are considered as active-reactive power sources (i.e. Type 4).

\section{Investigated cases}

As previously mentioned, in this paper, 62 case studies are investigated as shown in Table 3. 
CASE 1.1 through CASE 1.31 are related to the first test system whilst CASE 2.1 trough CASE 2.31 are related to the second test system. CASE 1.1 and CASE 2.1 are base cases where no DG is inserted, these cases are investigated to serve as a reference for the remaining cases for comparison purposes. For the remaining cases the objective is to improve $\lambda_{\max }$.

CASE 1.2 to CASE 1.6 are related to one DG unit using a unity power factor and different penetration levels. CASE 1.7 to CASE 1.11 are related to one DG unit with different penetration levels but with an optimized power factor.

CASE 1.12 to CASE 1.16 are related to two DG units using a unity power factor and different penetration levels. CASE 1.17 to CASE 1.21 are related to two DG units with different penetration levels but with an optimized power factor.

CASE 1.22 to CASE 1.26 are related to three DG units using a unity power factor and different penetration levels. CASE 1.27 to CASE 1.31 are related to three DG units with different penetration levels but with an optimized power factor.

Finally, the same description can be made for the cases that are related to the second test system.

Table 3. Summary of the Studied Cases

\begin{tabular}{|c|c|c|c|c|}
\hline CASE & No. DG & $\mathrm{DG}_{\mathrm{PL}}$ & $\mathrm{PF}$ & Test system (radial system) \\
\hline CASE1.1/CASE2.1 & - & - & - & 33-bus/69-bus \\
\hline CASE1.2/CASE2.2 & 1 & 0.25 & 1 & 33-bus/69-bus \\
\hline CASE1.3/CASE2.3 & 1 & 0.5 & 1 & 33-bus/69-bus \\
\hline CASE1.4/CASE2.4 & 1 & 0.75 & 1 & 33-bus/69-bus \\
\hline CASE1.5/CASE 2.5 & 1 & 1 & 1 & 33-bus/69-bus \\
\hline CASE1.6/CASE 2.6 & 1 & 2 & 1 & 33-bus/69-bus \\
\hline CASE1.7/CASE 2.7 & 1 & 0.25 & Design variable & 33-bus/69-bus \\
\hline CASE1.8/CASE 2.8 & 1 & 0.5 & Design variable & 33-bus/69-bus \\
\hline CASE1.9/CASE 2.9 & 1 & 0.75 & Design variable & 33-bus/69-bus \\
\hline CASE1.10/CASE 2.10 & 1 & 1 & Design variable & 33-bus/69-bus \\
\hline CASE1.11/CASE 2.11 & 1 & 2 & Design variable & 33-bus/69-bus \\
\hline CASE1.12/CASE 2.12 & 2 & 0.25 & 1 & 33-bus/69-bus \\
\hline CASE1.13/CASE 2.13 & 2 & 0.5 & 1 & 33-bus/69-bus \\
\hline CASE1.14/CASE 2.14 & 2 & 0.75 & 1 & 33-bus/69-bus \\
\hline CASE1.15/CASE 2.15 & 2 & 1 & 1 & 33-bus/69-bus \\
\hline CASE1.16/CASE 2.16 & 2 & 2 & 1 & 33-bus/69-bus \\
\hline CASE1.17/CASE 2.17 & 2 & 0.25 & Design variable & 33-bus/69-bus \\
\hline CASE1.18/CASE 2.18 & 2 & 0.5 & Design variable & 33-bus/69-bus \\
\hline CASE1.19/CASE 2.19 & 2 & 0.75 & Design variable & 33-bus/69-bus \\
\hline CASE1.20/CASE 2.20 & 2 & 1 & Design variable & 33-bus/69-bus \\
\hline CASE1.21/CASE 2.21 & 2 & 2 & Design variable & 33-bus/69-bus \\
\hline CASE1.22/CASE 2.22 & 3 & 0.25 & 1 & 33-bus/69-bus \\
\hline CASE1.23/CASE 2.23 & 3 & 0.5 & 1 & 33-bus/69-bus \\
\hline CASE1.24/CASE 2.24 & 3 & 0.75 & 1 & 33-bus/69-bus \\
\hline CASE1.25/CASE 2.25 & 3 & 1 & 1 & 33-bus/69-bus \\
\hline CASE1.26/CASE 2.26 & 3 & 2 & 1 & 33-bus/69-bus \\
\hline CASE1.27/CASE 2.27 & 3 & 0.25 & Design variable & 33-bus/69-bus \\
\hline CASE1.28/CASE 2.28 & 3 & 0.5 & Design variable & 33-bus/69-bus \\
\hline CASE1.29/CASE 2.29 & 3 & 0.75 & Design variable & 33-bus /69-bus \\
\hline CASE1.30/CASE 2.30 & 3 & 1 & Design variable & 33-bus/69-bus \\
\hline CASE1.31/CASE 2.31 & 3 & 2 & Design variable & 33-bus/69-bus \\
\hline
\end{tabular}

The developed program has been implemented using the commercial MATLAB software (version R2015a). The simulation runs were performed using the proposed VS based approach with $\mathrm{n}=50$, and a maximum of 150 iterations.

\section{Results for the 33-bus radial test system}

Results for one DG unit incorporation

The obtained results for the incorporation of one DG unit for the 33-bus RTS are presented in Table 4. The following comments can be made on this table:

a. For the base case without DG (i.e. CASE 1.1), $\lambda_{\max }=3.406$. In this case NBVV=21.

b. For CASE 1.2, CASE 1.3 and CASE 1.7, NBVV is equal to 6, 4 and 5 respectively. Even though the NBVV has been reduced from 21 in the base case to 6,4 and 5 in these cases, the network is still not fully optimized due to incorporation of only one DG and due to the limitation on the penetration level.

c. The location of the DG unit is between buses 8 and 13 . 
d. For CASE 1.4, using only one DG unit but with a penetration level of $75 \%$ the network is optimized and the NBVV=0. The maximum loadability in this case has been increased from 3.406 to 4.195 compared with the base case i.e. SLI=23.14\%.

e. For CASE 1.5, the SLI is $25.07 \%$ while it is $26.88 \%$ in CASE 1.6 where no constraint is imposed on the penetration level of DG.

f. For CASE 1.8, even though only one DG unit is incorporated using a penetration lever of $50 \%$ the network is optimized (NBVV=0) compared with CASE 1.3 because the PF has been computed as 0.88 instead of 1 for CASE 1.3.

g. For CASE 1.9 and 1.10 the SLIs are $25.93 \%$ and $26.88 \%$ compared with the base case.

h. The PV curves of CASE 1.1, CASE 1.5 and CASE 1.10 are displayed in Figure 5.

i. The voltage profile is improved in all cases in comparison to the base case as shown by the VPI. The best improvement is obtained for CASE 1.6 where VPI=88.206\%. The voltage profile of CASE 1.1, CASE 1.5 and CASE 1.10 are displayed in Figure 6.

j. The active power losses are reduced in some cases as for CASE 1.8 and CASE 1.9 and they are increased in other cases as for CASE 1.4, CASE 1.5, CASE 1.6, CASE 1.10 and CASE 1.11

k. The evolution of the objective function for CASE 1.5 and CASE 1.10 is given in Figure 7.

\section{Results for two DG units incorporation}

The obtained results for the incorporation of two DG units for the 33-bus RTS are given in Table 5. The following comments can be made on this table:

a. When incorporating two DG units only one case is not optimized where NBVV=15 that is CASE 1.12.

b. The location of the first DG unit is between buses 14 and 18 while the location of the second DG unit is between buses 31 and 32 for all cases.

c. The most important SLI is for CASE 1.21 where it is equal to $47.86 \%$. An illustration of the PV curves of CASE 1.1, CASE 1.15 and CASE 1.20 is given in Figure 8.

d. The voltage profile is improved in all cases compared with the base case. An illustration of VP for CASE 1.1, CASE 1.15 and CASE 1.20 is given in Figure 9.

e. Active power losses are reduced in almost all cases except CASE 1.16 where there is an increase of $48.06 \%$.

f. When the PF is not fixed and it is considered as a design variable, it varies approximatively between 0.82 and 0.95 .

g. The evolution of the objective function for CASE 1.15 and CASE 1.20 is sketched in Figure 10.

Results for three DG units incorporation

The obtained results for the incorporation of three DG units for the 33-bus RTS are given in Table 6. The following comments can be made on this table:

a. When incorporating three DG units only one case is not optimized where NBVV=5 that is CASE 1.22.

b. The location of DG units is mainly at busses 10, 14, 15, 16, 17, 18, 30, 31 and 32 .

c. The best SLI obtained is for CASE 1.31 where it is equal to 48.64\%. An illustration of the PV curves of CASE 1.1, CASE 1.25 and CASE 1.30 is given in Figure 11.

d. The voltage profile is improved in all cases compared with the base case. An illustration of VP for CASE 1.1, CASE 1.25 and CASE 1.30 is given in Figure 12.

e. Active power losses are reduced in all cases compared with the base case except for CASE 1.26.

f. When the PF is not fixed and it is considered as a design variable, it varies approximatively between 0.81 and 0.90 .

The evolution of the objective function for CASE 1.25 and CASE 1.30 is given in Figure 13. 
Table 4. Obtained Results for the 33-bus RTS for One DG Unit

\begin{tabular}{|c|c|c|c|c|c|c|c|c|c|c|c|c|c|c|c|c|c|c|}
\hline \multirow[b]{2}{*}{ CASE \# } & \multicolumn{3}{|c|}{ Location } & \multicolumn{3}{|c|}{ Size (P [MW]) } & \multirow[b]{2}{*}{$\mathrm{PF}$} & \multirow[b]{2}{*}{$\mathrm{DG}_{\mathrm{PL}}$} & \multirow[b]{2}{*}{$\lambda_{\max }$} & \multirow[b]{2}{*}{$P_{\text {Losses }}$} & \multirow[b]{2}{*}{ VSI } & \multirow[b]{2}{*}{ VP } & \multicolumn{6}{|c|}{ Performance evaluation indices } \\
\hline & $\mathrm{DG}_{1}$ & $\mathrm{DG}_{2}$ & $\begin{array}{c}\mathrm{DG} \\
3\end{array}$ & $\mathrm{DG}_{1}$ & $\mathrm{DG}_{2}$ & $\mathrm{DG}_{3}$ & & & & & & & ALR & RLR & SLI & VPI & VSIM & NBVV \\
\hline $\begin{array}{c}\text { CASE } \\
1.1\end{array}$ & - & - & - & - & - & - & - & - & $\begin{array}{c}3.40 \\
6\end{array}$ & 0.211 & 1 & 0.134 & - & - & - & - & - & 21 \\
\hline $\begin{array}{c}\text { CASE } \\
1.2\end{array}$ & 13 & - & - & 0.930 & - & - & 1 & 25 & $\begin{array}{c}3.80 \\
5\end{array}$ & 0.132 & 1 & 0.052 & $\begin{array}{c}37.23 \\
1\end{array}$ & $\begin{array}{c}38.0 \\
81\end{array}$ & $\begin{array}{c}11.6 \\
96\end{array}$ & $\begin{array}{c}61.3 \\
71\end{array}$ & $\mathbf{0}$ & 6 \\
\hline $\begin{array}{c}\text { CASE } \\
1.3\end{array}$ & 8 & - & - & 1.858 & - & - & 1 & 50 & $\begin{array}{c}3.81 \\
4\end{array}$ & 0.118 & 1 & 0.034 & $\begin{array}{c}43.95 \\
7\end{array}$ & $\begin{array}{c}41.6 \\
60\end{array}$ & $\begin{array}{c}11.9 \\
54\end{array}$ & $\begin{array}{c}74.5 \\
55\end{array}$ & $\mathbf{0}$ & 4 \\
\hline $\begin{array}{c}\text { CASE } \\
1.4\end{array}$ & 13 & - & - & 2.780 & - & - & 1 & 75 & $\begin{array}{c}4.19 \\
5\end{array}$ & 0.248 & $\begin{array}{c}0.82 \\
7\end{array}$ & 0.027 & $\begin{array}{c}- \\
17.69 \\
3\end{array}$ & $\begin{array}{c}- \\
26.3 \\
55\end{array}$ & $\begin{array}{c}23.1 \\
35\end{array}$ & $\begin{array}{c}79.8 \\
05\end{array}$ & 17.275 & 0 \\
\hline $\begin{array}{c}\text { CASE } \\
1.5\end{array}$ & 10 & - & - & 3.499 & - & - & 1 & 100 & $\begin{array}{c}4.26 \\
0\end{array}$ & 0.275 & $\begin{array}{c}0.82 \\
5\end{array}$ & 0.025 & $\begin{array}{c}- \\
30.48 \\
3\end{array}$ & $\begin{array}{c}- \\
47.7 \\
43\end{array}$ & $\begin{array}{c}25.0 \\
70\end{array}$ & $\begin{array}{c}81.6 \\
18\end{array}$ & 17.517 & 0 \\
\hline $\begin{array}{c}\text { CASE } \\
1.6\end{array}$ & 8 & - & - & 4.809 & - & - & 1 & - & $\begin{array}{c}4.32 \\
2\end{array}$ & 0.327 & $\begin{array}{c}0.83 \\
3\end{array}$ & 0.016 & $\begin{array}{c}- \\
54.80 \\
9\end{array}$ & $\begin{array}{c}- \\
87.9 \\
17\end{array}$ & $\begin{array}{c}26.8 \\
76\end{array}$ & $\begin{array}{c}88.2 \\
06\end{array}$ & 16.678 & 0 \\
\hline $\begin{array}{c}\text { CASE } \\
1.7\end{array}$ & 12 & - & - & 0.922 & - & - & $\begin{array}{c}0.84 \\
4\end{array}$ & 25 & $\begin{array}{c}3.86 \\
2\end{array}$ & 0.105 & 1 & 0.036 & $\begin{array}{c}50.18 \\
9\end{array}$ & $\begin{array}{c}50.8 \\
85\end{array}$ & $\begin{array}{c}13.3 \\
73\end{array}$ & $\begin{array}{c}73.1 \\
20\end{array}$ & $\mathbf{0}$ & 5 \\
\hline $\begin{array}{c}\text { CASE } \\
1.8\end{array}$ & 13 & - & - & 1.932 & - & - & $\begin{array}{c}0.88 \\
4\end{array}$ & 50 & $\begin{array}{c}4.19 \\
8\end{array}$ & 0.131 & $\begin{array}{c}0.82 \\
6\end{array}$ & 0.028 & $\begin{array}{c}38.14 \\
5\end{array}$ & $\begin{array}{c}34.2 \\
53\end{array}$ & $\begin{array}{c}23.2 \\
21\end{array}$ & $\begin{array}{c}79.3 \\
27\end{array}$ & 17.416 & 0 \\
\hline $\begin{array}{c}\text { CASE } \\
1.9\end{array}$ & 9 & - & - & 3.099 & - & - & $\begin{array}{c}0.94 \\
7\end{array}$ & 75 & $\begin{array}{c}4.29 \\
0\end{array}$ & 0.155 & $\begin{array}{c}0.82 \\
4\end{array}$ & 0.021 & $\begin{array}{c}26.69 \\
3\end{array}$ & $\begin{array}{c}13.4 \\
04\end{array}$ & $\begin{array}{c}25.9 \\
30\end{array}$ & $\begin{array}{c}84.4 \\
84\end{array}$ & 17.571 & 0 \\
\hline $\begin{array}{c}\text { CASE } \\
1.10\end{array}$ & 8 & - & - & 4.200 & - & - & $\begin{array}{c}0.98 \\
8\end{array}$ & 100 & $\begin{array}{c}4.32 \\
2\end{array}$ & 0.222 & $\begin{array}{c}0.83 \\
1\end{array}$ & 0.016 & $\begin{array}{c}- \\
5.393\end{array}$ & $\begin{array}{c}- \\
29.7 \\
02\end{array}$ & $\begin{array}{c}26.8 \\
76\end{array}$ & $\begin{array}{c}88.1 \\
54\end{array}$ & 16.944 & 0 \\
\hline $\begin{array}{c}\text { CASE } \\
1.11\end{array}$ & 8 & - & - & 4.522 & - & - & $\begin{array}{c}0.99 \\
8\end{array}$ & - & $\begin{array}{c}4.32 \\
3\end{array}$ & 0.273 & $\begin{array}{c}0.83 \\
2\end{array}$ & 0.016 & $\begin{array}{c}- \\
29.27 \\
1\end{array}$ & $\begin{array}{c}- \\
57.8 \\
50\end{array}$ & $\begin{array}{c}26.9 \\
19\end{array}$ & $\begin{array}{c}88.1 \\
38\end{array}$ & 16.845 & 0 \\
\hline
\end{tabular}

Table 5. Obtained Results for the 33-bus RTS for Two DG Units

\begin{tabular}{|c|c|c|c|c|c|c|c|c|c|c|c|c|c|c|c|c|c|c|}
\hline \multirow{2}{*}{$\begin{array}{c}\text { CASE } \\
\#\end{array}$} & \multicolumn{3}{|c|}{ Location } & \multicolumn{3}{|c|}{ Size (P [MW]) } & \multirow[b]{2}{*}{ PF } & \multirow[b]{2}{*}{$\mathrm{DG}_{\mathrm{PL}}$} & \multirow[b]{2}{*}{$\lambda_{\max }$} & \multirow[b]{2}{*}{$P_{\text {Losses }}$} & \multirow[b]{2}{*}{ VSI } & \multirow[b]{2}{*}{ VP } & \multicolumn{6}{|c|}{ Performance evaluation indices } \\
\hline & $\mathrm{DG}_{1}$ & $\mathrm{DG}_{2}$ & $\mathrm{DG}_{3}$ & $\mathrm{DG}_{1}$ & $\mathrm{DG}_{2}$ & $\mathrm{DG}_{3}$ & & & & & & & ALR & RLR & SLI & VPI & VSIM & NBVV \\
\hline $\begin{array}{c}\text { CASE } \\
1.1\end{array}$ & - & - & - & - & - & - & - & - & 3.406 & 0.211 & 1 & $\begin{array}{l}\mathbf{0 . 1} \\
34\end{array}$ & - & - & - & - & - & 21 \\
\hline $\begin{array}{c}\text { CASE } \\
1.12\end{array}$ & 18 & 32 & - & $\begin{array}{c}0.46 \\
6\end{array}$ & $\begin{array}{c}0.46 \\
6\end{array}$ & - & 1 & 25 & 3.828 & 0.119 & 1 & $\begin{array}{c}0.0 \\
56\end{array}$ & $\begin{array}{c}43.4 \\
16\end{array}$ & $\begin{array}{c}44.1 \\
01\end{array}$ & $\begin{array}{c}12.3 \\
84\end{array}$ & $\begin{array}{c}58.2 \\
14\end{array}$ & $\mathbf{0}$ & 15 \\
\hline $\begin{array}{c}\text { CASE } \\
1.13\end{array}$ & 17 & 32 & - & $\begin{array}{c}0.92 \\
7\end{array}$ & $\begin{array}{c}0.92 \\
8\end{array}$ & - & 1 & 50 & 4.176 & 0.100 & 1 & $\begin{array}{c}0.0 \\
16\end{array}$ & $\begin{array}{c}52.7 \\
53\end{array}$ & $\begin{array}{c}49.5 \\
81\end{array}$ & $\begin{array}{c}22.5 \\
76\end{array}$ & $\begin{array}{c}87.8 \\
88\end{array}$ & 0 & 0 \\
\hline $\begin{array}{c}\text { CASE } \\
1.14\end{array}$ & 17 & 32 & - & $\begin{array}{c}1.39 \\
3\end{array}$ & $\begin{array}{c}1.39 \\
2\end{array}$ & - & 1 & 75 & 4.474 & 0.140 & $\begin{array}{c}0.91 \\
3\end{array}$ & $\begin{array}{c}0.0 \\
04\end{array}$ & $\begin{array}{c}33.7 \\
67\end{array}$ & $\begin{array}{c}22.8 \\
96\end{array}$ & $\begin{array}{c}31.3 \\
48\end{array}$ & $\begin{array}{c}96.9 \\
32\end{array}$ & 8.732 & 0 \\
\hline $\begin{array}{c}\text { CASE } \\
1.15\end{array}$ & 16 & 32 & - & $\begin{array}{c}1.85 \\
7\end{array}$ & $\begin{array}{c}1.85 \\
7\end{array}$ & - & 1 & 100 & 4.748 & 0.209 & $\begin{array}{c}0.83 \\
3\end{array}$ & $\begin{array}{c}0.0 \\
12\end{array}$ & $\begin{array}{c}0.94 \\
0\end{array}$ & $\begin{array}{c}11.3 \\
24\end{array}$ & $\begin{array}{c}39.3 \\
89\end{array}$ & $\begin{array}{c}90.7 \\
61\end{array}$ & 16.687 & 0 \\
\hline $\begin{array}{c}\text { CASE } \\
1.16\end{array}$ & 14 & 31 & - & $\begin{array}{c}1.89 \\
7\end{array}$ & $\begin{array}{c}2.93 \\
4\end{array}$ & - & 1 & - & 4.959 & 0.312 & $\begin{array}{c}0.82 \\
3\end{array}$ & $\begin{array}{l}0.0 \\
29\end{array}$ & $\begin{array}{c}- \\
48.0 \\
59\end{array}$ & $\begin{array}{c}- \\
64.8 \\
42\end{array}$ & $\begin{array}{c}45.5 \\
82\end{array}$ & $\begin{array}{c}78.4 \\
23\end{array}$ & 17.695 & 0 \\
\hline $\begin{array}{c}\text { CASE } \\
1.17\end{array}$ & 17 & 32 & - & $\begin{array}{c}0.46 \\
4\end{array}$ & $\begin{array}{c}0.46 \\
5\end{array}$ & - & $\begin{array}{c}0.8 \\
52\end{array}$ & 25 & 3.991 & 0.082 & 1 & $\begin{array}{l}0.0 \\
33\end{array}$ & $\begin{array}{c}61.3 \\
63\end{array}$ & $\begin{array}{c}62.1 \\
03\end{array}$ & $\begin{array}{c}17.1 \\
58\end{array}$ & $\begin{array}{c}75.0 \\
58\end{array}$ & 0 & 0 \\
\hline $\begin{array}{c}\text { CASE } \\
1.18\end{array}$ & 17 & 32 & - & $\begin{array}{c}0.89 \\
9\end{array}$ & $\begin{array}{c}0.89 \\
9\end{array}$ & - & $\begin{array}{l}0.8 \\
24\end{array}$ & 50 & 4.505 & 0.051 & $\begin{array}{c}0.89 \\
9\end{array}$ & $\begin{array}{c}0.0 \\
05\end{array}$ & $\begin{array}{c}75.9 \\
42\end{array}$ & $\begin{array}{c}71.3 \\
38\end{array}$ & $\begin{array}{c}32.2 \\
51\end{array}$ & $\begin{array}{c}96.3 \\
85\end{array}$ & 10.148 & 0 \\
\hline $\begin{array}{c}\text { CASE } \\
1.19\end{array}$ & 14 & 32 & - & $\begin{array}{c}1.43 \\
3\end{array}$ & $\begin{array}{c}1.43 \\
3\end{array}$ & - & $\begin{array}{l}0.8 \\
75\end{array}$ & 75 & 4.920 & 0.071 & $\begin{array}{c}0.82 \\
3\end{array}$ & $\begin{array}{c}0.0 \\
19\end{array}$ & $\begin{array}{c}66.4 \\
22\end{array}$ & $\begin{array}{c}59.8 \\
26\end{array}$ & $\begin{array}{c}44.4 \\
21\end{array}$ & $\begin{array}{c}85.4 \\
46\end{array}$ & 17.683 & 0 \\
\hline $\begin{array}{c}\text { CASE } \\
1.20\end{array}$ & 14 & 32 & - & $\begin{array}{c}1.38 \\
5\end{array}$ & $\begin{array}{c}1.97 \\
1\end{array}$ & - & $\begin{array}{l}0.9 \\
02\end{array}$ & 100 & 5.024 & 0.099 & $\begin{array}{c}0.82 \\
3\end{array}$ & $\begin{array}{l}0.0 \\
27\end{array}$ & $\begin{array}{c}53.3 \\
02\end{array}$ & $\begin{array}{c}43.4 \\
12\end{array}$ & $\begin{array}{c}47.4 \\
74\end{array}$ & $\begin{array}{c}79.8 \\
37\end{array}$ & 17.713 & 0 \\
\hline $\begin{array}{c}\text { CASE } \\
1.21 \\
\end{array}$ & 15 & 31 & - & $\begin{array}{c}1.38 \\
1 \\
\end{array}$ & $\begin{array}{c}2.30 \\
5 \\
\end{array}$ & - & $\begin{array}{l}0.9 \\
45 \\
\end{array}$ & - & 5.037 & 0.124 & $\begin{array}{c}0.82 \\
3 \\
\end{array}$ & $\begin{array}{l}0.0 \\
27 \\
\end{array}$ & $\begin{array}{c}41.1 \\
40 \\
\end{array}$ & $\begin{array}{c}31.2 \\
22 \\
\end{array}$ & $\begin{array}{c}47.8 \\
61 \\
\end{array}$ & $\begin{array}{c}79.5 \\
70 \\
\end{array}$ & 17.706 & 0 \\
\hline
\end{tabular}


Table 6. Obtained Results for the 33-bus RTS for Three DG Units

\begin{tabular}{|c|c|c|c|c|c|c|c|c|c|c|c|c|c|c|c|c|c|c|}
\hline \multirow[b]{2}{*}{$\begin{array}{c}\text { CASE } \\
\#\end{array}$} & \multicolumn{3}{|c|}{ Location } & \multicolumn{3}{|c|}{ Size (P [MW]) } & \multirow[b]{2}{*}{ PF } & \multirow[b]{2}{*}{$\mathrm{DG}_{\mathrm{PL}}$} & \multirow[b]{2}{*}{$\lambda_{\max }$} & \multirow[b]{2}{*}{$P_{\text {Losses }}$} & \multirow[b]{2}{*}{ VSI } & \multirow[b]{2}{*}{ VP } & \multicolumn{6}{|c|}{ Performance evaluation indices } \\
\hline & $\mathrm{DG}_{1}$ & $\mathrm{DG}_{2}$ & $\mathrm{DG}_{3}$ & $\mathrm{DG}_{1}$ & $\mathrm{DG}_{2}$ & $\mathrm{DG}_{3}$ & & & & & & & ALR & RLR & SLI & VPI & VSIM & NBVV \\
\hline $\begin{array}{c}\text { CASE } \\
1.1\end{array}$ & - & - & - & - & - & - & - & - & 3.406 & 0.211 & 1 & 0.134 & - & - & - & - & - & 21 \\
\hline $\begin{array}{c}\text { CASE } \\
1.22\end{array}$ & 14 & 17 & 32 & 0.310 & 0.310 & 0.311 & 1 & 25 & 3.843 & 0.118 & 1 & 0.053 & 43.865 & 45.172 & 12.814 & 60.272 & $\mathbf{0}$ & 5 \\
\hline $\begin{array}{c}\text { CASE } \\
1.23\end{array}$ & 15 & 18 & 32 & 0.618 & 0.617 & 0.619 & 1 & 50 & 4.187 & 0.107 & 1 & 0.015 & 49.263 & 47.059 & 22.920 & 88.422 & 0 & 0 \\
\hline $\begin{array}{c}\text { CASE } \\
1.24\end{array}$ & 15 & 17 & 32 & 0.928 & 0.929 & 0.929 & 1 & 75 & 4.463 & 0.155 & 0.865 & 0.010 & 26.562 & 17.411 & 31.004 & 92.732 & 13.511 & 0 \\
\hline $\begin{array}{c}\text { CASE } \\
1.25\end{array}$ & 10 & 16 & 32 & 1.238 & 1.238 & 1.238 & 1 & 100 & 4.684 & 0.189 & 0.828 & 0.016 & 10.421 & 0.843 & 37.497 & 87.801 & 17.243 & 0 \\
\hline $\begin{array}{c}\text { CASE } \\
1.26\end{array}$ & 14 & 17 & 31 & 1.003 & 0.746 & 2.926 & 1 & - & 4.977 & 0.296 & 0.823 & 0.025 & $\begin{array}{c}- \\
40.088\end{array}$ & $\begin{array}{c}- \\
57.031\end{array}$ & 46.098 & 80.953 & 17.698 & 0 \\
\hline $\begin{array}{c}\text { CASE } \\
1.27\end{array}$ & 10 & 14 & 32 & 0.296 & 0.296 & 0.296 & 0.814 & 25 & 3.916 & 0.083 & 1 & 0.035 & 60.522 & 62.071 & 14.965 & 73.469 & 0 & 0 \\
\hline $\begin{array}{c}\text { CASE } \\
1.28\end{array}$ & 14 & 17 & 32 & 0.627 & 0.630 & 0.630 & 0.865 & 50 & 4.473 & 0.059 & 0.867 & 0.010 & 71.836 & 68.994 & 31.305 & 92.621 & 13.344 & 0 \\
\hline $\begin{array}{c}\text { CASE } \\
1.29\end{array}$ & 18 & 31 & 32 & 0.912 & 0.910 & 0.903 & 0.835 & 75 & 4.861 & 0.077 & 0.828 & 0.014 & 63.663 & 53.814 & 42.700 & 89.359 & 17.187 & 0 \\
\hline $\begin{array}{c}\text { CASE } \\
1.30\end{array}$ & 15 & 30 & 31 & 1.232 & 1.151 & 1.192 & 0.905 & 100 & 5.052 & 0.097 & 0.823 & 0.029 & 53.882 & 47.934 & 48.291 & 78.095 & 17.710 & 0 \\
\hline $\begin{array}{c}\text { CASE } \\
1.31\end{array}$ & 14 & 17 & 30 & 0.906 & 0.185 & 2.212 & 0.810 & - & 5.063 & 0.091 & 0.823 & 0.032 & 56.902 & 51.934 & 48.635 & 75.889 & 17.724 & 0 \\
\hline
\end{tabular}

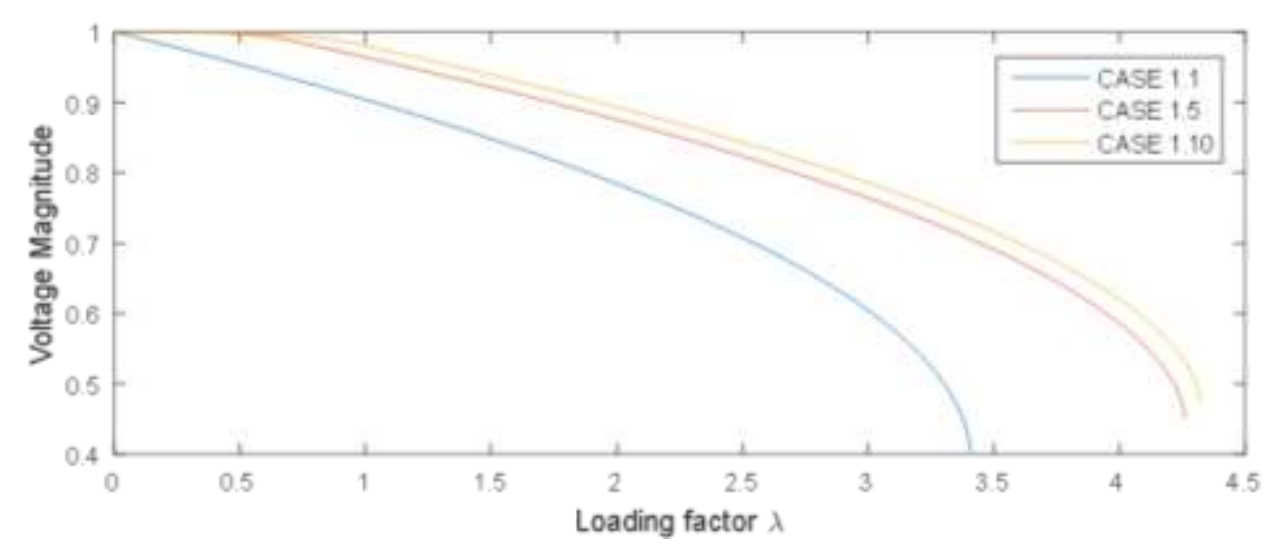

Figure 5. System maximum loading curves for CASE 1.1, CASE 1.5 and CASE 1.10

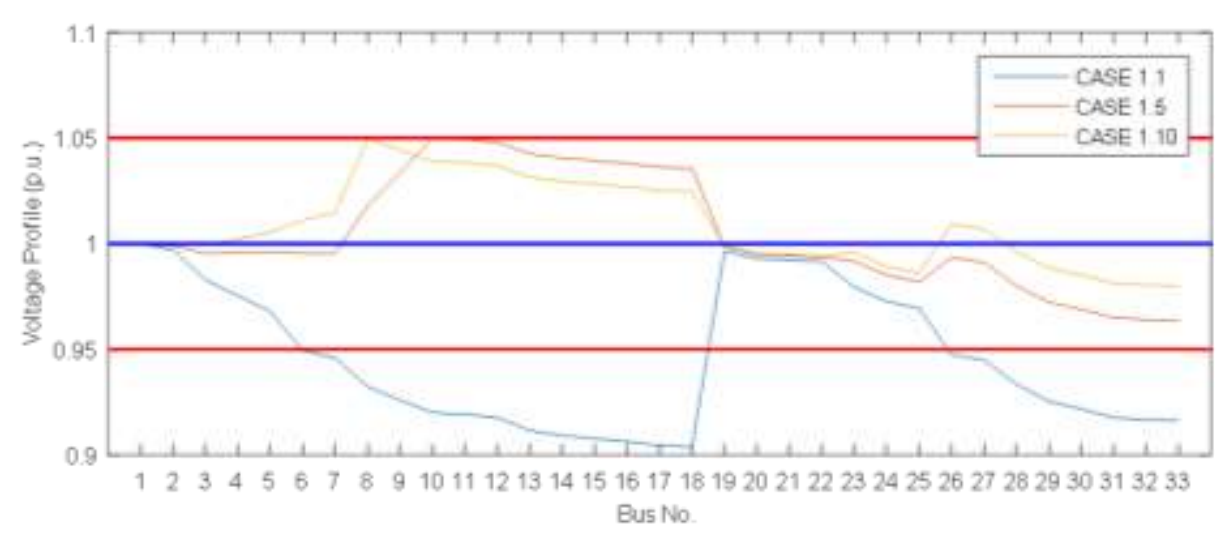

Figure 6. Voltage profiles for CASE 1.1, CASE 1.5 and CASE 1.10 


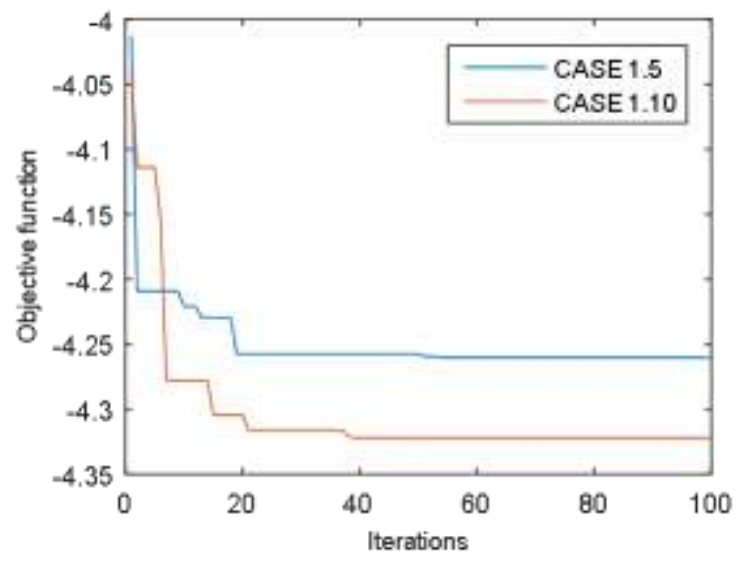

Figure 7. Evolution of the objective function for CASE 1.5 and CASE 1.10

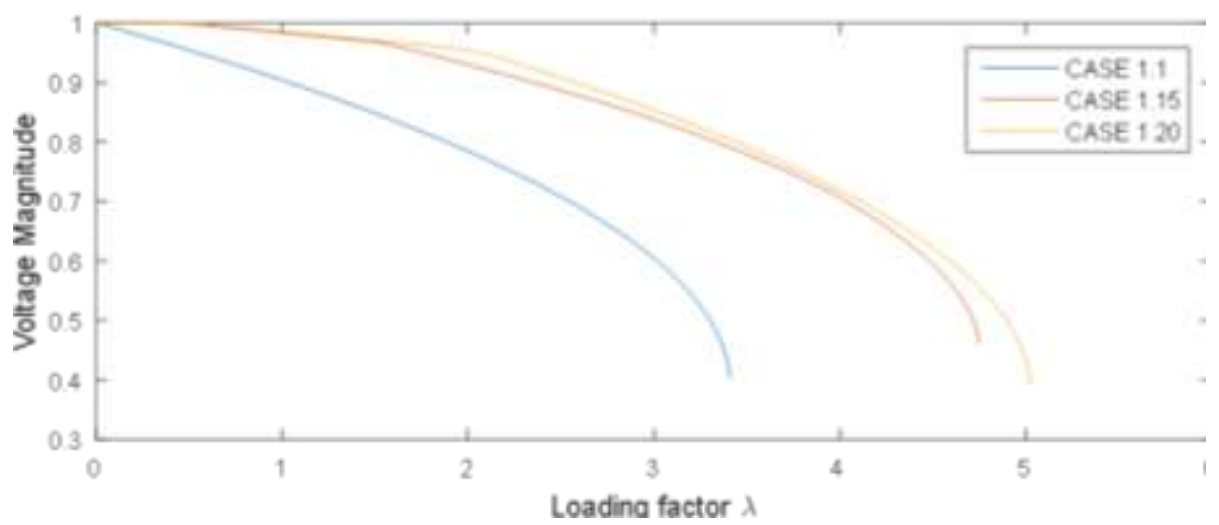

Figure 8. System maximum loading curves for CASE 1.1, CASE 1.15 and CASE 1.20

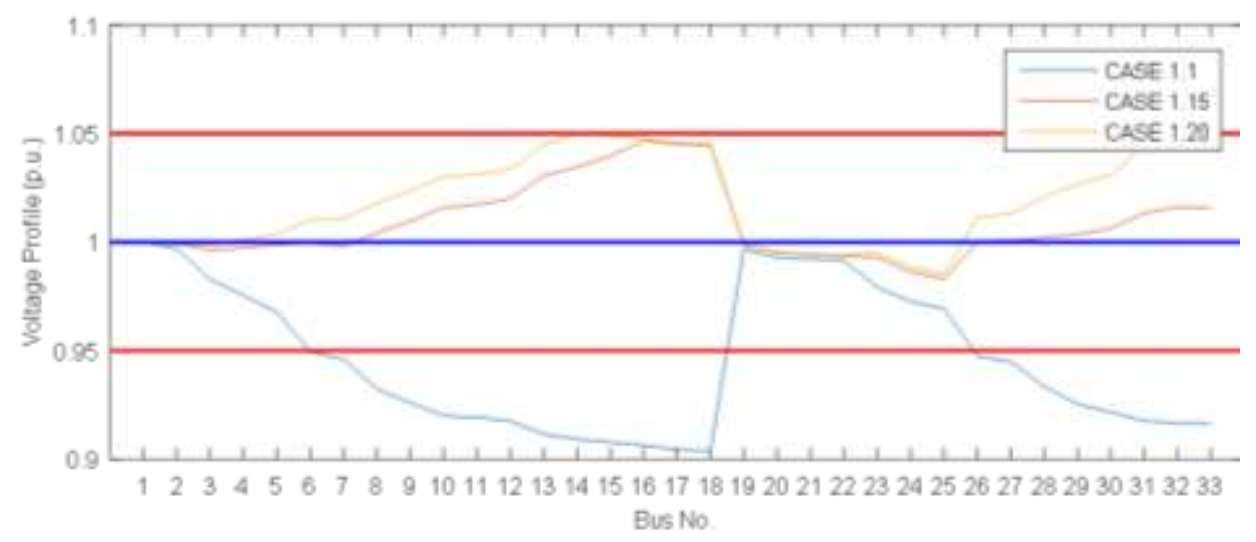

Figure 9. Voltage profiles for CASE 1.1, CASE 1.15 and CASE 1.20. 


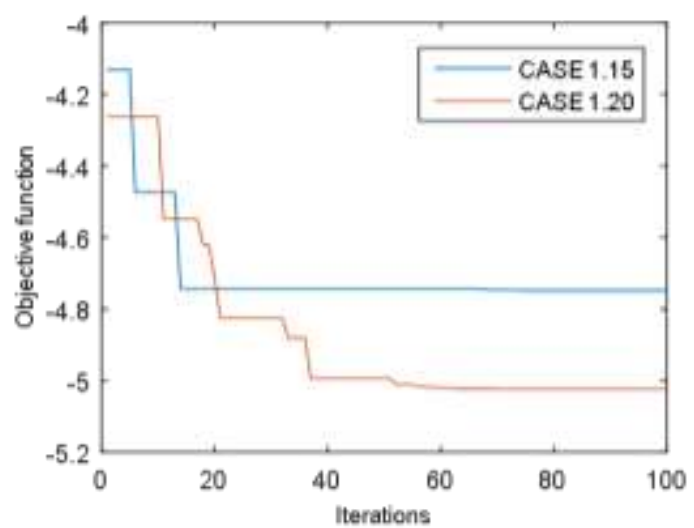

Figure 10. Evolution of the objective function for CASE 1.15 and CASE 1.20

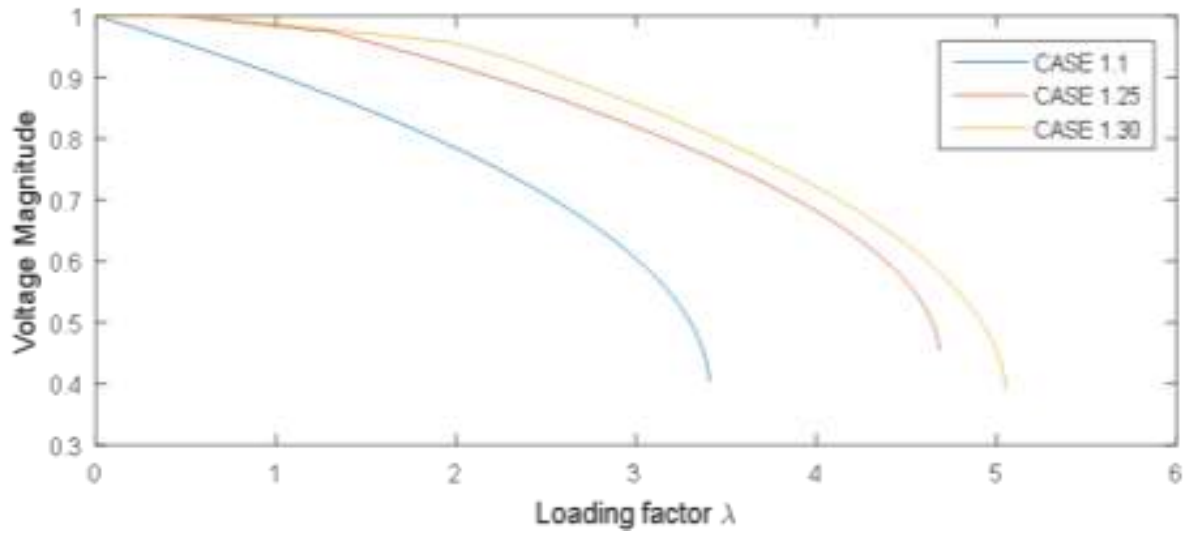

Figure 11. System maximum loading curves for CASE 1.1, CASE 1.25 and CASE 1.30

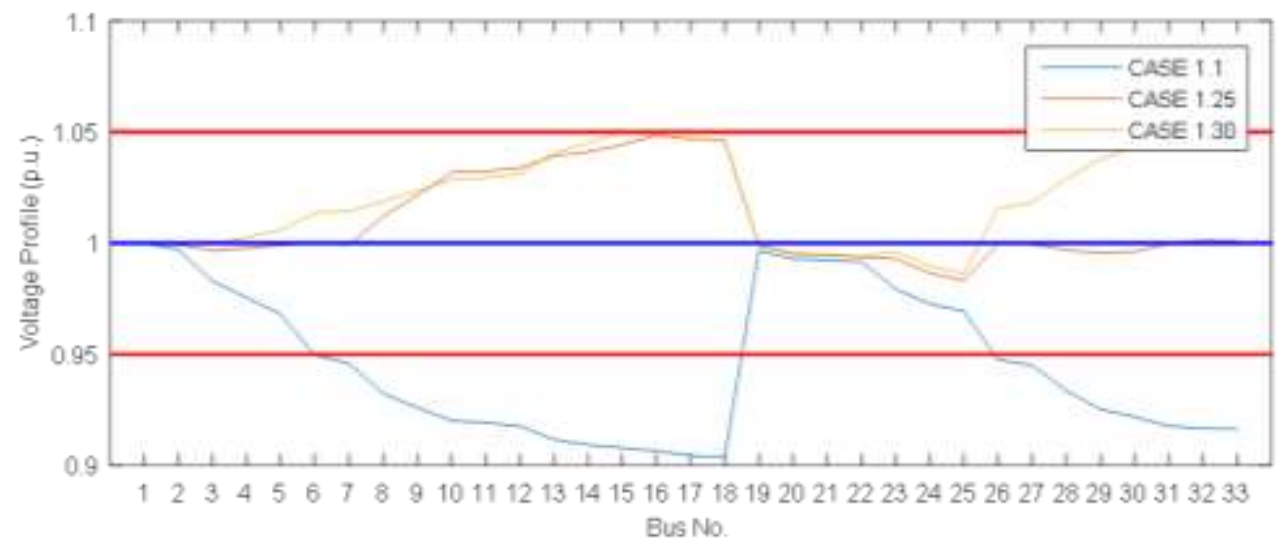

Figure 12. Voltage profiles for CASE 1.1, CASE 1.25 and CASE 1.30 


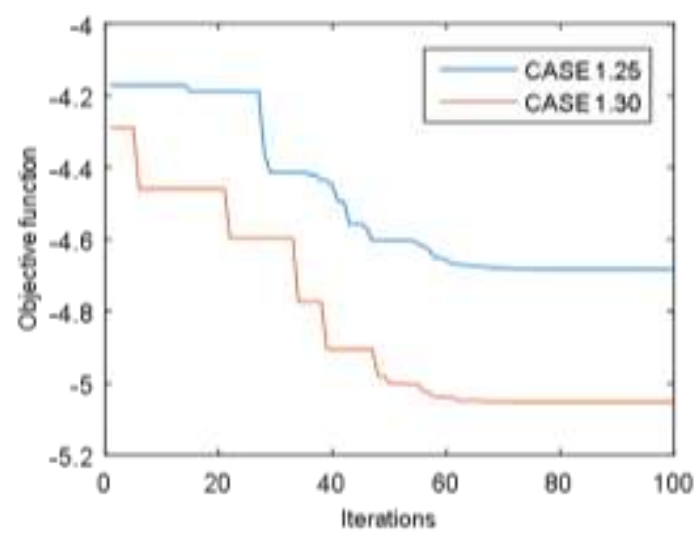

Figure 13. Evolution of the objective function for CASE 1.25 and CASE 1.30

\section{Results for the 69-bus radial test system}

Results for one DG unit incorporation

The obtained results for the incorporation of one DG unit for the 69-bus RTS are given in Table7. The following comments can be made on this table:

a. For the base case without DG (i.e. CASE 2.1) the maximum loadability is 3.21. In this case NBVV=9.

b. For CASE 2.2 NBVV is equal to 3. Even though the NBVV has been decreased from 9 in the base case to 3 in this case, the network is still not fully optimized due to incorporation of only one DG and the limitation imposed on the penetration level ( $25 \%$ only).

c. DG units are located mainly in busses $61,62,63$ and 64 .

d. For CASE 2.3, using only one DG unit but with a penetration level of $50 \%$ the network is optimized and the NBVV=0. The $\lambda_{\max }$ in this case has been increased from 3.210 to 3.966 compared with the base case i.e. SLI $=23.55 \%$. Likewise, for CASE 2.4 and CASE 2.5 with $\mathrm{DG}_{\mathrm{PL}}=75 \%$ and $\mathrm{DG}_{\mathrm{PL}}=100 \%$, the SLI is equal to $34.22 \%$ and $44.86 \%$, respectively.

e. For CASE 2.7, even though only one DG unit is incorporated using a penetration lever of $25 \%$ the network is optimized (NBVV=0) compared with CASE 2.2 because the PF has been computed as 0.89 instead of 1 for CASE 2.2.

f. The PV curves of CASE 2.1, CASE 2.5 and CASE 2.10 are displayed in Figure 14.

g. In all cases, voltage profile is better than the base case as shown by the VPI. The best improvement is obtained for CASE 2.4 where VPI $=88.14 \%$. The voltage profile of CASE 2.1, CASE 2.5 and CASE 2.10 are displayed in Figure 15.

h. The active power losses is reduced in all cases.

i. The evolution of the objective function for CASE 2.5 and CASE 2.10 is given in Figure 16.

\section{Results for two DG units incorporation}

The obtained results for the incorporation of two DG units for the 69-bus RTS are given in Table 8. The following comments can be made on this table:

a. When incorporating two DG units only one case is not optimized where NBVV=3 that is CASE 2.12.

b. The first DG unit is located at buses $38,61,62$, and 63 while the location of the second DG unit is mainly on buses $61,62,63,64$ and 65 .

c. The most important SLI is for CASE 2.21 where it is equal to 53.25\%. An illustration of the PV curves of CASE 2.1, CASE 2.15 and CASE 2.20 is given in Figure 17.

d. The voltage profile is improved in all cases compared with the base case. An illustration of VP for CASE 2.1, CASE 2.15 and CASE 2.20 is given in Figure 18.

e. Active power losses are reduced in all cases.

f. When the PF is not fixed and it is considered as a design variable, it varies approximatively between 0.80 and 0.90 .

g. The evolution of the objective function for CASE 2.15 and CASE 2.20 is sketched in Figure 19.

\section{Results for three DG units incorporation}

The obtained results for the incorporation of three DG units for the 69-bus RTS are shown in Table 9. The following comments can be made on this table:

a. When incorporating three DG units only one case is not optimized where NBVV=4 that is CASE 2.22. 
b. The best SLI obtained is for CASE 2.31 where it is equal to $53.11 \%$. An illustration of the PV curves of CASE 2.1, CASE 2.21 and CASE 2.25 is given in Figure 20.

c. The voltage profile is improved in all cases compared with the base case. An illustration of VP for CASE 2.1, CASE 2.21 and CASE 2.25 is given in Figure 21.

d. Active power losses are reduced in all cases compared with the base case.

e. When the PF is not fixed and it is considered as a design variable, it varies approximately between 0.81 and 0.98 .

The evolution of the objective function for CASE 2.21 and CASE 2.25 is given in Figure 22.

Table 7. Obtained Results for the 69-bus RTS for One DG Unit

\begin{tabular}{|c|c|c|c|c|c|c|c|c|c|c|c|c|c|c|c|c|c|c|}
\hline \multirow{2}{*}{$\begin{array}{c}\text { CASE } \\
\#\end{array}$} & \multicolumn{3}{|c|}{ Location } & \multicolumn{3}{|c|}{ Size (P [MW]) } & \multirow[b]{2}{*}{$\mathrm{PF}$} & \multirow[b]{2}{*}{$\mathrm{DG}_{\mathrm{PL}}$} & \multirow[b]{2}{*}{$\lambda_{\max }$} & \multirow[b]{2}{*}{$P_{\text {Losses }}$} & \multirow[b]{2}{*}{ VSI } & \multirow[b]{2}{*}{$\mathrm{VP}$} & \multicolumn{6}{|c|}{ Performance evaluation indices } \\
\hline & $\mathrm{DG}_{1}$ & $\mathrm{DG}_{2}$ & $\mathrm{DG}_{3}$ & $\mathrm{DG}_{1}$ & $\mathrm{DG}_{2}$ & $\mathrm{DG}_{3}$ & & & & & & & ALR & RLR & SLI & VPI & VSIM & NBVV \\
\hline $\begin{array}{c}\text { CASE } \\
2.1\end{array}$ & - & - & - & - & - & - & - & - & 3.210 & 0.225 & 1 & 0.099 & - & - & - & - & - & 9 \\
\hline $\begin{array}{c}\text { CASE } \\
2.2\end{array}$ & 64 & - & - & 0.951 & - & - & 1 & 25 & 3.604 & 0.118 & 1 & 0.046 & 47.736 & 44.796 & 12.275 & $\mathbf{5 3 . 9 5 2}$ & $\mathbf{0}$ & 3 \\
\hline $\begin{array}{c}\text { CASE } \\
2.3\end{array}$ & 64 & - & - & 1.900 & - & - & 1 & 50 & 3.966 & 0.099 & 1 & 0.019 & 55.938 & 52.470 & 23.546 & 80.803 & 0 & 0 \\
\hline $\begin{array}{c}\text { CASE } \\
2.4\end{array}$ & 62 & - & - & 2.851 & - & - & 1 & 75 & 4.309 & 0.118 & 0.940 & 0.012 & 47.456 & 47.201 & 34.223 & 88.174 & 5.969 & 0 \\
\hline $\begin{array}{c}\text { CASE } \\
2.5\end{array}$ & 61 & - & - & 3.801 & - & - & 1 & 100 & 4.650 & 0.198 & 0.843 & 0.020 & 11.904 & 16.461 & 44.855 & 80.339 & 15.692 & 0 \\
\hline $\begin{array}{c}\text { CASE } \\
2.6\end{array}$ & 61 & - & - & 4.011 & - & - & 1 & 200 & 4.725 & 0.223 & 0.823 & 0.023 & 0.919 & 6.733 & 47.182 & 76.688 & 17.689 & 0 \\
\hline $\begin{array}{c}\text { CASE } \\
2.7\end{array}$ & 64 & - & - & 1.029 & - & - & 0.885 & 25 & 3.771 & 0.071 & 1 & 0.033 & 68.505 & 64.326 & 17.477 & 66.536 & 0 & 0 \\
\hline $\begin{array}{c}\text { CASE } \\
2.8\end{array}$ & 64 & - & - & 2.011 & - & - & 0.863 & 50 & 4.307 & 0.046 & 0.938 & 0.012 & 79.370 & 74.578 & 34.178 & 88.095 & 6.156 & 0 \\
\hline $\begin{array}{c}\text { CASE } \\
2.9\end{array}$ & 63 & - & - & 2.999 & - & - & 0.858 & 75 & 4.817 & 0.085 & 0.827 & 0.020 & 62.283 & 61.809 & 50.057 & 79.611 & 17.266 & 0 \\
\hline $\begin{array}{c}\text { CASE } \\
2.10\end{array}$ & 61 & - & - & 3.008 & - & - & 0.800 & 100 & 4.920 & 0.093 & 0.823 & 0.022 & 58.603 & 60.160 & 53.251 & 77.565 & 17.712 & 0 \\
\hline $\begin{array}{c}\text { CASE } \\
2.11 \\
\end{array}$ & 61 & - & - & 3.008 & - & - & 0.800 & 200 & 4.920 & 0.093 & 0.823 & 0.022 & 58.603 & 60.160 & 53.251 & 77.565 & 17.712 & 0 \\
\hline
\end{tabular}

Table 8. Obtained Results for the 69-bus RTS for Two DG Units

\begin{tabular}{|c|c|c|c|c|c|c|c|c|c|c|c|c|c|c|c|c|c|c|}
\hline \multirow{2}{*}{$\begin{array}{c}\text { CASE } \\
\#\end{array}$} & \multicolumn{3}{|c|}{ Location } & \multicolumn{3}{|c|}{ Size (P [MW]) } & \multirow[b]{2}{*}{ PF } & \multirow[b]{2}{*}{$\mathrm{DG}_{\mathrm{PL}}$} & \multirow[b]{2}{*}{$\lambda_{\max }$} & \multirow[b]{2}{*}{$\mathrm{P}_{\text {Losses }}$} & \multirow[b]{2}{*}{ VSI } & \multirow[b]{2}{*}{ VP } & \multicolumn{6}{|c|}{ Performance evaluation indices } \\
\hline & $\mathrm{DG}_{1}$ & $\mathrm{DG}_{2}$ & $\mathrm{DG}_{3}$ & $\mathrm{DG}_{1}$ & $\mathrm{DG}_{2}$ & $\mathrm{DG}_{3}$ & & & & & & & ALR & RLR & SLI & VPI & VSIM & NBVV \\
\hline $\begin{array}{c}\text { CASE } \\
2.1\end{array}$ & - & - & - & - & - & - & - & - & $\begin{array}{c}3.2 \\
10\end{array}$ & 0.225 & 1 & $\begin{array}{l}0.0 \\
99\end{array}$ & - & - & - & - & - & 9 \\
\hline $\begin{array}{c}\text { CASE } \\
2.12\end{array}$ & 63 & 65 & - & $\begin{array}{c}0.47 \\
5\end{array}$ & 0.475 & - & 1 & 25 & $\begin{array}{l}3.6 \\
00\end{array}$ & 0.117 & 1 & $\begin{array}{c}0.0 \\
46\end{array}$ & $\begin{array}{c}48.1 \\
21\end{array}$ & $\begin{array}{c}45.2 \\
20\end{array}$ & $\begin{array}{c}12.1 \\
38\end{array}$ & $\begin{array}{c}53.8 \\
74\end{array}$ & 0 & 3 \\
\hline $\begin{array}{c}\text { CASE } \\
2.13\end{array}$ & 62 & 64 & - & $\begin{array}{c}0.95 \\
0\end{array}$ & 0.949 & - & 1 & 50 & $\begin{array}{l}3.9 \\
72\end{array}$ & 0.087 & 1 & $\begin{array}{c}0.0 \\
19\end{array}$ & $\begin{array}{c}61.3 \\
93\end{array}$ & $\begin{array}{c}58.5 \\
61\end{array}$ & $\begin{array}{c}23.7 \\
28\end{array}$ & $\begin{array}{c}80.7 \\
85\end{array}$ & 0 & 0 \\
\hline $\begin{array}{c}\text { CASE } \\
2.14\end{array}$ & 61 & 64 & - & $\begin{array}{c}1.42 \\
4\end{array}$ & 1.424 & - & 1 & 75 & $\begin{array}{l}4.3 \\
29\end{array}$ & 0.121 & 0.925 & $\begin{array}{c}0.0 \\
12\end{array}$ & $\begin{array}{c}46.1 \\
58\end{array}$ & $\begin{array}{c}45.7 \\
10\end{array}$ & $\begin{array}{c}34.8 \\
62\end{array}$ & $\begin{array}{c}87.7 \\
59\end{array}$ & 7.540 & 0 \\
\hline $\begin{array}{c}\text { CASE } \\
2.15\end{array}$ & 61 & 63 & - & $\begin{array}{c}1.90 \\
0\end{array}$ & 1.901 & - & 1 & 100 & $\begin{array}{c}4.6 \\
57\end{array}$ & 0.201 & 0.836 & $\begin{array}{l}0.0 \\
20\end{array}$ & $\begin{array}{c}10.4 \\
87\end{array}$ & $\begin{array}{c}14.8 \\
47\end{array}$ & $\begin{array}{c}45.0 \\
83\end{array}$ & $\begin{array}{c}79.5 \\
92\end{array}$ & 16.377 & 0 \\
\hline $\begin{array}{c}\text { CASE } \\
2.16\end{array}$ & 61 & 65 & - & $\begin{array}{c}3.96 \\
7\end{array}$ & 0.044 & - & 1 & 200 & $\begin{array}{l}4.7 \\
26\end{array}$ & 0.223 & 0.823 & $\begin{array}{l}0.0 \\
23\end{array}$ & $\begin{array}{c}1.00 \\
8\end{array}$ & $\begin{array}{c}6.82 \\
7\end{array}$ & $\begin{array}{c}47.2 \\
28\end{array}$ & $\begin{array}{c}76.6 \\
13\end{array}$ & 17.686 & 0 \\
\hline $\begin{array}{c}\text { CASE } \\
2.17\end{array}$ & 63 & 64 & - & $\begin{array}{c}0.52 \\
3\end{array}$ & 0.523 & - & $\begin{array}{c}0.8 \\
98\end{array}$ & 25 & $\begin{array}{l}3.7 \\
65\end{array}$ & 0.068 & 1 & $\begin{array}{l}0.0 \\
33\end{array}$ & $\begin{array}{c}69.5 \\
76\end{array}$ & $\begin{array}{c}65.5 \\
70\end{array}$ & $\begin{array}{c}17.2 \\
94\end{array}$ & $\begin{array}{c}66.3 \\
08\end{array}$ & 0 & 0 \\
\hline $\begin{array}{c}\text { CASE } \\
2.18\end{array}$ & 63 & 64 & - & $\begin{array}{c}0.95 \\
2\end{array}$ & 0.952 & - & $\begin{array}{c}0.8 \\
17\end{array}$ & 50 & $\begin{array}{l}4.3 \\
07\end{array}$ & 0.031 & 0.962 & $\begin{array}{c}0.0 \\
11\end{array}$ & $\begin{array}{c}86.1 \\
19\end{array}$ & $\begin{array}{c}82.0 \\
68\end{array}$ & $\begin{array}{c}34.1 \\
78\end{array}$ & $\begin{array}{c}88.4 \\
43\end{array}$ & 3.774 & 0 \\
\hline $\begin{array}{c}\text { CASE } \\
2.19\end{array}$ & 61 & 64 & - & $\begin{array}{c}1.40 \\
9\end{array}$ & 1.410 & - & $\begin{array}{c}0.8 \\
08\end{array}$ & 75 & $\begin{array}{l}4.8 \\
44\end{array}$ & 0.080 & 0.823 & $\begin{array}{l}0.0 \\
20\end{array}$ & $\begin{array}{c}64.5 \\
05\end{array}$ & $\begin{array}{c}64.1 \\
65\end{array}$ & $\begin{array}{c}50.8 \\
78\end{array}$ & $\begin{array}{c}80.3 \\
01\end{array}$ & 17.707 & 0 \\
\hline $\begin{array}{c}\text { CASE } \\
2.20\end{array}$ & 61 & 62 & - & $\begin{array}{c}1.87 \\
1\end{array}$ & 1.134 & - & $\begin{array}{l}0.8 \\
06\end{array}$ & 100 & $\begin{array}{c}4.9 \\
14\end{array}$ & 0.091 & 0.823 & $\begin{array}{l}0.0 \\
22\end{array}$ & $\begin{array}{c}59.6 \\
12\end{array}$ & $\begin{array}{c}60.9 \\
88\end{array}$ & $\begin{array}{c}53.0 \\
69\end{array}$ & $\begin{array}{c}77.6 \\
30\end{array}$ & 17.727 & 0 \\
\hline $\begin{array}{c}\text { CASE } \\
2.21\end{array}$ & 38 & 61 & - & $\begin{array}{c}0.11 \\
2\end{array}$ & 3.008 & - & $\begin{array}{c}0.8 \\
00\end{array}$ & 200 & $\begin{array}{l}4.9 \\
20 \\
\end{array}$ & 0.093 & 0.823 & $\begin{array}{l}0.0 \\
22\end{array}$ & $\begin{array}{c}58.6 \\
30\end{array}$ & $\begin{array}{c}60.2 \\
30 \\
\end{array}$ & $\begin{array}{c}53.2 \\
51 \\
\end{array}$ & $\begin{array}{c}77.5 \\
76\end{array}$ & 17.709 & 0 \\
\hline
\end{tabular}


Table 9. Obtained Results for the 69-bus RTS for Three DG Units

\begin{tabular}{|c|c|c|c|c|c|c|c|c|c|c|c|c|c|c|c|c|c|c|}
\hline \multirow{2}{*}{$\begin{array}{c}\text { CASE } \\
\# \\
\end{array}$} & \multicolumn{3}{|c|}{ Location } & \multicolumn{3}{|c|}{ Size (P [MW]) } & \multirow[b]{2}{*}{$\mathrm{PF}$} & \multirow[b]{2}{*}{$\mathrm{DG}_{\mathrm{PL}}$} & \multirow[b]{2}{*}{$\lambda_{\max }$} & \multirow[b]{2}{*}{$\mathrm{P}_{\text {Losses }}$} & \multirow[b]{2}{*}{ VSI } & \multirow[b]{2}{*}{ VP } & \multicolumn{6}{|c|}{ Performance evaluation indices } \\
\hline & $\mathrm{DG}_{1}$ & $\mathrm{DG}_{2}$ & $\mathrm{DG}_{3}$ & $\mathrm{DG}_{1}$ & $\mathrm{DG}_{2}$ & $\mathrm{DG}_{3}$ & & & & & & & ALR & RLR & SLI & VPI & VSIM & NBVV \\
\hline $\begin{array}{c}\text { CASE } \\
2.1\end{array}$ & - & - & - & - & - & - & - & - & 3.210 & 0.225 & 1 & 0.099 & - & - & - & - & - & 9 \\
\hline $\begin{array}{c}\text { CASE } \\
2.22\end{array}$ & 61 & 62 & 65 & 0.317 & $\mathbf{0 . 3 1 7}$ & 0.317 & 1 & 25 & 3.597 & 0.115 & 1 & 0.046 & 48.915 & 46.094 & 12.047 & $\mathbf{5 3 . 4 5 3}$ & $\mathbf{0}$ & 4 \\
\hline $\begin{array}{c}\text { CASE } \\
2.23\end{array}$ & 61 & 63 & 64 & 0.633 & 0.631 & 0.633 & 1 & 50 & 3.969 & 0.085 & 1 & 0.019 & 62.313 & 59.584 & 23.637 & 80.675 & 0 & 0 \\
\hline $\begin{array}{c}\text { CASE } \\
2.24\end{array}$ & 17 & 62 & 64 & 0.806 & 0.948 & 0.949 & 1 & 75 & 4.011 & 0.079 & 0.990 & 0.002 & 64.887 & 62.013 & 24.960 & 97.994 & 0.994 & 0 \\
\hline $\begin{array}{c}\text { CASE } \\
2.25\end{array}$ & 61 & 62 & 64 & 1.267 & 1.267 & 1.266 & 1 & 100 & 4.674 & 0.205 & 0.826 & 0.021 & 9.094 & 13.241 & 45.585 & 78.702 & 17.429 & 0 \\
\hline $\begin{array}{c}\text { CASE } \\
2.26\end{array}$ & 17 & 46 & 61 & 0.008 & 0.023 & 4.010 & 1 & 200 & 4.725 & 0.223 & 0.823 & 0.023 & 1.064 & 6.860 & 47.182 & 76.850 & 17.693 & 0 \\
\hline $\begin{array}{c}\text { CASE } \\
2.27\end{array}$ & 59 & 63 & 65 & 0.340 & 0.338 & 0.339 & 0.876 & 25 & 3.713 & 0.072 & 1 & 0.035 & 68.066 & 64.199 & 15.651 & 64.794 & 0 & 0 \\
\hline $\begin{array}{c}\text { CASE } \\
2.28\end{array}$ & 63 & 64 & 65 & 0.757 & 0.757 & 0.757 & 0.975 & 50 & 4.249 & 0.065 & 0.937 & 0.012 & 70.901 & 67.222 & 32.352 & 87.522 & 6.272 & 0 \\
\hline $\begin{array}{c}\text { CASE } \\
2.29\end{array}$ & 9 & 61 & 64 & 0.802 & 0.979 & 0.979 & 0.841 & 75 & 4.357 & 0.021 & 0.943 & 0.007 & 90.507 & 87.183 & 35.729 & 93.240 & 5.695 & 0 \\
\hline $\begin{array}{c}\text { CASE } \\
2.30\end{array}$ & 62 & 64 & 67 & 1.449 & 1.451 & 1.444 & 0.934 & 100 & 4.725 & 0.081 & 0.824 & 0.017 & 64.029 & 61.687 & 47.182 & 83.358 & 17.574 & 0 \\
\hline $\begin{array}{c}\text { CASE } \\
2.31\end{array}$ & 1 & 32 & 61 & 2.266 & 0.885 & 3.029 & 0.809 & 200 & 4.915 & 0.097 & 0.823 & 0.022 & 56.749 & 58.053 & 53.114 & 77.415 & 17.698 & 0 \\
\hline
\end{tabular}

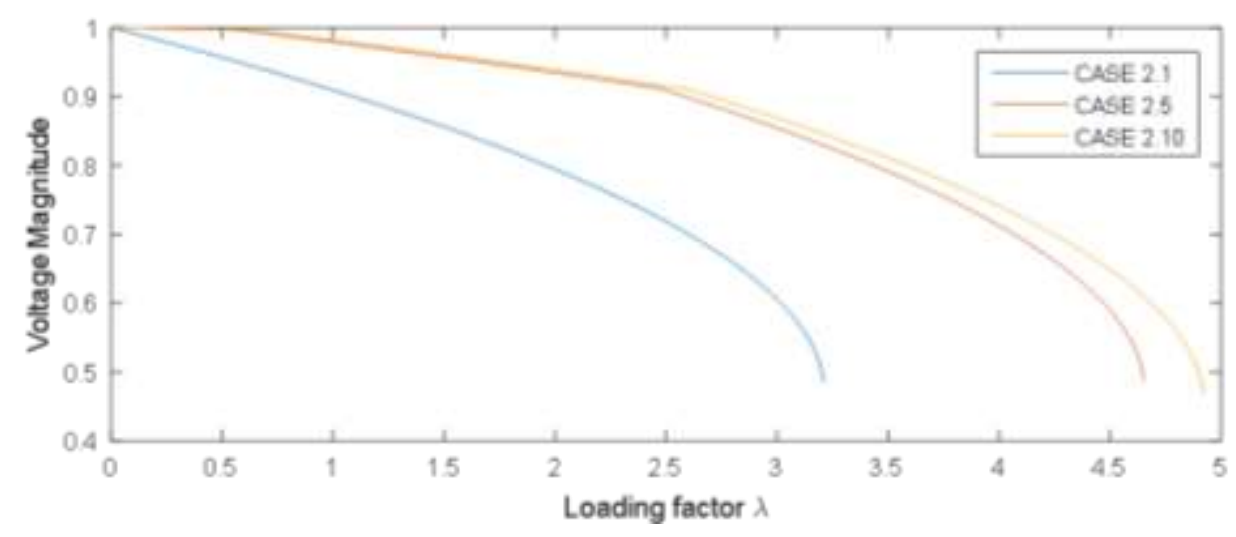

Figure 14. System maximum loading curves for CASE 2.1, CASE 2.5 and CASE 2.10

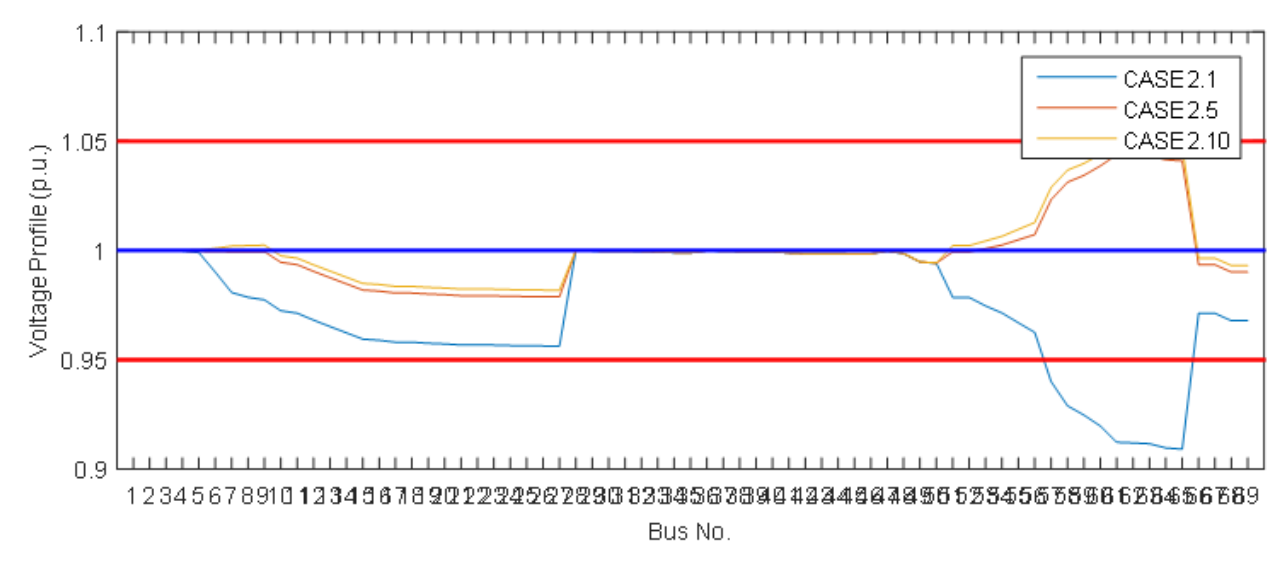

Figure 15. Voltage profiles for CASE 2.1, CASE 2.5 and CASE 2.10 


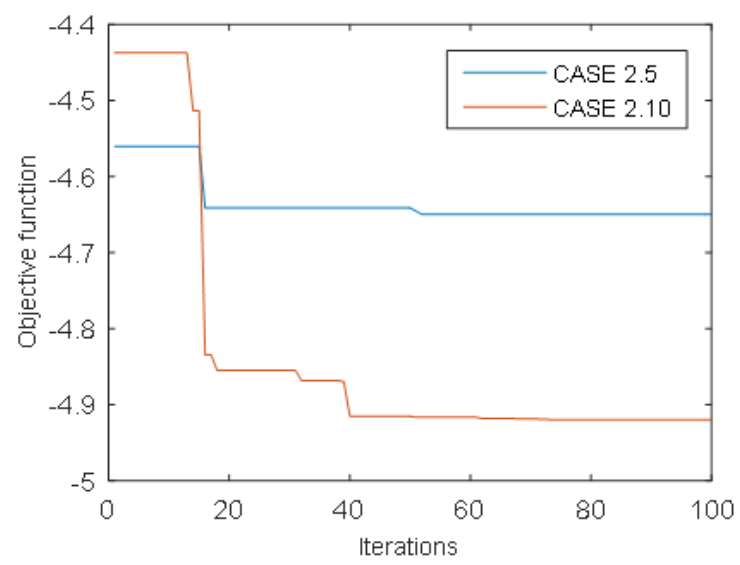

Figure 16. Evolution of the objective function for CASE 2.5 and CASE 2.10

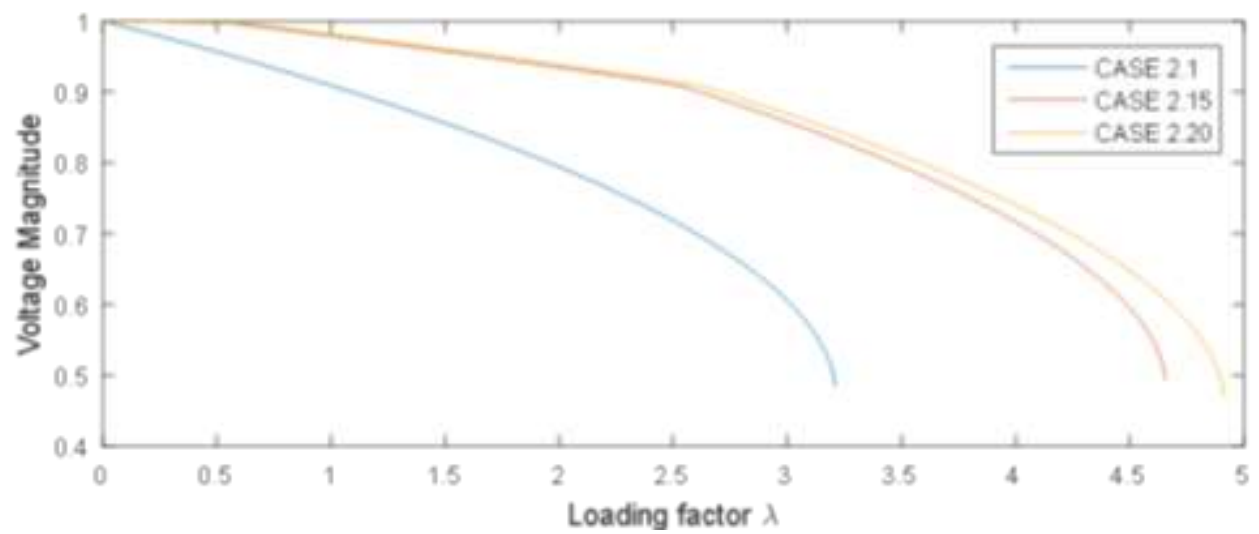

Figure 17. System maximum loading curves for CASE 2.1, CASE 2.15 and CASE 2.20

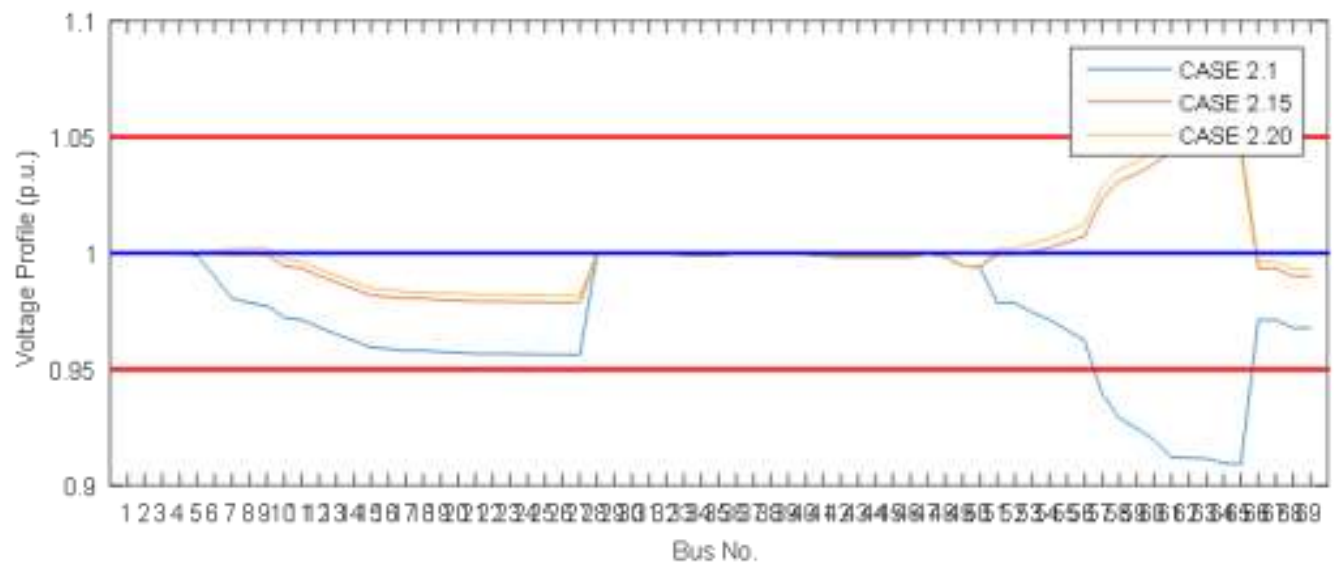

Figure 18. Voltage profiles for CASE 2.1, CASE 2.15 and CASE 2.20 


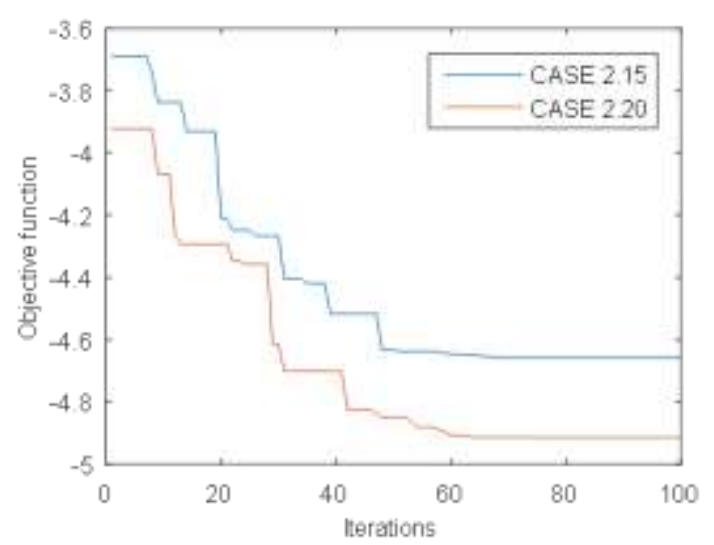

Figure 19. Evolution of the objective function for CASE 2.15 and CASE 2.20

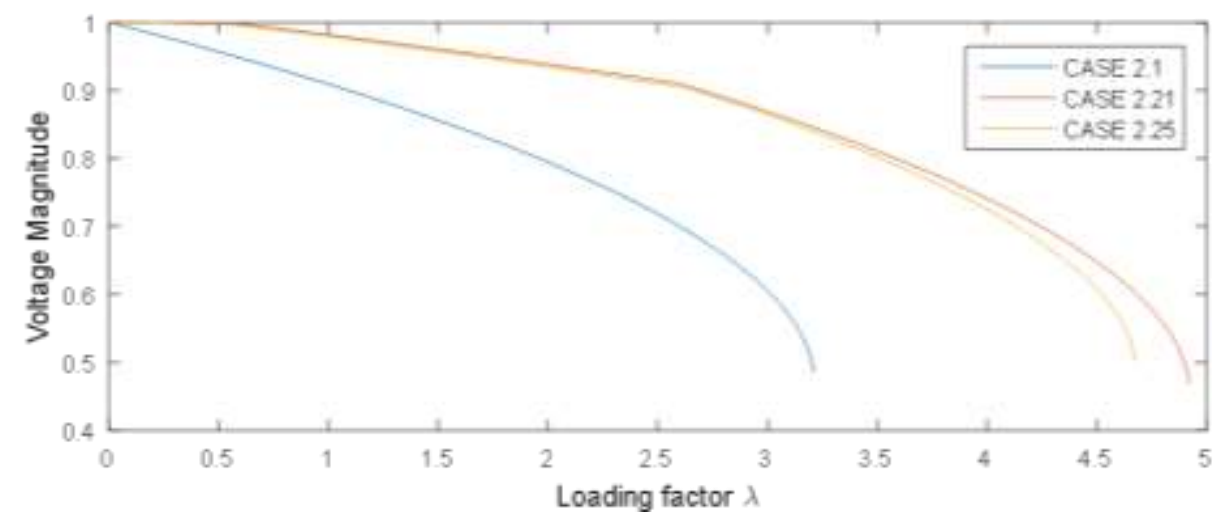

Figure 20. System maximum loading curves for CASE 2.1, CASE 2.21 and CASE 2.25

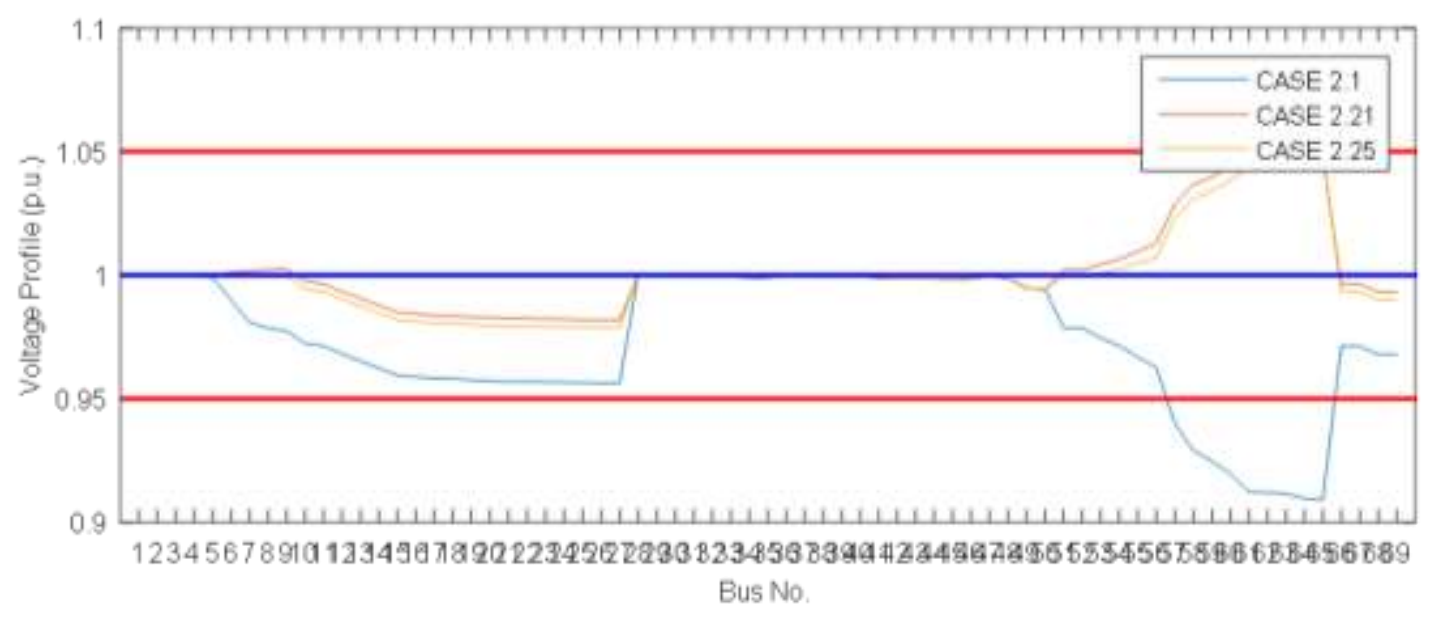

Figure 21. Voltage profiles for CASE 2.1, CASE 2.21 and CASE 2.25 


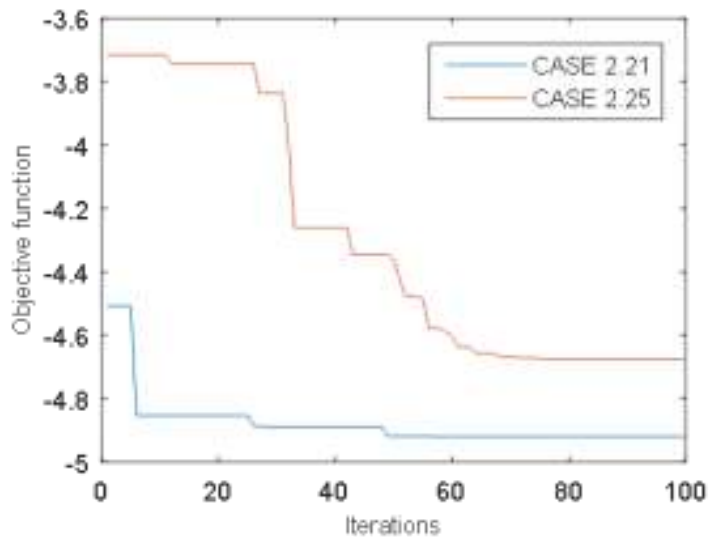

Figure 22. Evolution of the objective function for CASE 2.21 and CASE 2.25

\section{CONCLUSION}

This paper has investigated the optimal simultaneous incorporation of multiple distributed generation units for the maximization of the system loadability. The maximum loadability of the system is calculated using an accurate and fast approach compared with classical approach. The time gained by the proposed approach can be huge in an optimization procedure as for OIDG.

The OIDG in this paper has been solved using the vortex search algorithm. Many cases have been investigated using one, two and three DG units. Moreover, different penetration level of DG have been considered. In addition, in some cases the power factor is considered as unity and some other cases it is considered as a design variable in order to maximize the system loadability. From the obtained results, it can be concluded that; system loadability depends upon the level of DG penetration level. System loadability improves when the power factor of the generator changes i.e. when the generator supplies reactive power also. When the number of DG units is increased, the maximum loadability also improves. When the number of DG units is increased, the power system losses are reduced. Total number of DG units and their power factor changes the system loadability as well as power factor. Future research should concentrate on the investigation of a multi-objective OIDG problem.

\section{REFERENCES}

[1] T. Ackermann, G. Andersson, and L. Söder, "Distributed generation: A definition," Electr. Power Syst. Res., vol. 57, no. 3, pp. 195-204, 2001.

[2] N. Acharya, P. Mahat, and N. Mithulananthan, "An analytical approach for DG allocation in primary distribution network,” Int. J. Electr. Power Energy Syst., vol. 28, no. 10, pp. 669-678, 2006.

[3] G. Chicco and P. Mancarella, "Distributed multi-generation: A comprehensive view," Renew. Sustain. Energy Rev., vol. 13, no. 3, pp. 535-551, 2009.

[4] P. Chiradeja and R. Ramakumar, "An approach to quantify the technical benefits of distributed generation," IEEE Trans. Energy Convers., vol. 19, no. 4, pp. 764-773, 2004.

[5] A. A. Bayod-Rújula, "Future development of the electricity systems with distributed generation," Energy, vol. 34, no. 3, pp. 377-383, 2009.

[6] M. Zangiabadi, R. Feuillet, H. Lesani, N. Hadj-Said, and J. T. Kvaløy, “Assessing the performance and benefits of customer distributed generation developers under uncertainties," Energy, vol. 36, no. 3, pp. 1703-1712, 2011.

[7] A. Soroudi and M. Ehsan, "A distribution network expansion planning model considering distributed generation options and techo-economical issues," Energy, vol. 35, no. 8, pp. 3364-3374, 2010.

[8] H. L. Willis, "Analytical Methods and Rules of Thumb for Modeling Dg-Distribution Interaction.," Power Eng. Soc. Summer Meet. 2000. IEEE, vol. 3, no. c, pp. 1643-1644, 2000.

[9] C. Wang and M. H. Nehrir, "Analytical approaches for optimal placement of distributed generation sources in power systems," IEEE Trans. Power Syst., vol. 19, no. 4, pp. 2068-2076, 2004.

[10] T. Gözel and M. H. Hocaoglu, "An analytical method for the sizing and siting of distributed generators in radial systems," Electr. Power Syst. Res., vol. 79, no. 6, pp. 912-918, 2009.

[11] S. Ghosh, S. P. Ghoshal, and S. Ghosh, "Optimal sizing and placement of distributed generation in a network system,” Int. J. Electr. Power Energy Syst., vol. 32, no. 8, pp. 849-856, 2010.

[12] D. Q. Hung and N. Mithulananthan, "Multiple distributed generator placement in primary distribution networks for loss reduction," IEEE Trans. Ind. Electron., vol. 60, no. 4, pp. 1700-1708, 2013.

[13] C. L. T. Borges and D. M. Falcão, "Optimal distributed generation allocation for reliability, losses, and voltage improvement,” Int. J. Electr. Power Energy Syst., vol. 28, no. 6, pp. 413-420, 2006. 
[14] K. H. Kim, Y. J. Lee, S. B. Rhee, S. K. Lee, and S. K. You, "Dispersed generator placement using fuzzy-GA in distribution systems," Proc. IEEE Power Eng. Soc. Transm. Distrib. Conf., vol. 3, no. SUMMER, pp. 1148-1153, 2002.

[15] M. H. Moradi and M. Abedini, "A combination of genetic algorithm and particle swarm optimization for optimal DG location and sizing in distribution systems," Int. J. Electr. Power Energy Syst., vol. 34, no. 1, pp. 66-74, 2012.

[16] M. F. Akorede, H. Hizam, I. Aris, and M. Z. a. Ab Kadir, "Effective method for optimal allocation of distributed generation units in meshed electric power systems," IET Gener. Transm. Distrib., vol. 5, no. 2, p. 276, 2011.

[17] N. Khalesi, N. Rezaei, and M. R. Haghifam, "DG allocation with application of dynamic programming for loss reduction and reliability improvement," Int. J. Electr. Power Energy Syst., vol. 33, no. 2, pp. 288-295, 2011.

[18] L. W. L. Wang and C. Singh, "Reliability-Constrained Optimum Placement of Reclosers and Distributed Generators in Distribution Networks Using an Ant Colony System Algorithm," IEEE Trans. Syst. Man, Cybern. Part C (Applications Rev., vol. 38, no. 6, pp. 757-764, 2008.

[19] W. Krueasuk and W. Ongsakul, "Optimal placement of distributed generation using Particle Swarm Optimization," Australas. Univ. Power Eng. Conf. - AUPEC, p. 6, 2006.

[20] Z. Moravej and A. Akhlaghi, "A novel approach based on cuckoo search for DG allocation in distribution network,” Int. J. Electr. Power Energy Syst., vol. 44, no. 1, pp. 672-679, 2013.

[21] M. M. Aman, G. B. Jasmon, A. H. A. Bakar, and H. Mokhlis, "A new approach for optimum simultaneous multiDG distributed generation Units placement and sizing based on maximization of system loadability using HPSO (hybrid particle swarm optimization) algorithm," Energy, vol. 66, pp. 202-215, 2014.

[22] Y. Latreche, H. R. E. H. Bouchekara, F. Kerrour, K. Naidu, H. Mokhlis, and M. S. Javaid, "Comprehensive review on the optimal integration of distributed generation in distribution systems," J. Renew. Sustain. Energy, vol. 10, no. $5,2018$.

[23] M. Karen Nan and C. Hsiao-Dong, "Electric distribution system load capability: problem formulation, solution algorithm, and numerical results," Power Deliv. IEEE Trans., vol. 15, no. 1, pp. 436-442, 2000.

[24] N. C. Hien, N. Mithulananthan, and R. C. Bansal, "Location and sizing of distributed generation units for loadabilty enhancement in primary feeder," IEEE Syst. J., vol. 7, no. 4, pp. 797-806, 2013.

[25] N. Hemdan and M. Kurrat, "Influence of distributed generation on different loadability aspects of electric distribution systems," IET Conf. Publ., no. 0255, pp. 255-255, 2009.

[26] M. Alonso and H. Amarís, "Voltage stability in distribution networks with DG," 2009 IEEE Bucharest PowerTech Innov. Ideas Towar. Electr. Grid Futur., pp. 1-6, 2009.

[27] N. Mithulananthan and T. Oo, "Distributed generator placement to maximize the loadability of a distribution system,” Int. J. Electr. Eng. Educ., vol. 43, no. 2, pp. 107-118, 2006.

[28] B. Venkatesh, R. Ranjan, and H. B. Gooi, "Optimal Reconfiguration of Radial Distribution Systems to Maximize Loadability," IEEE Trans. Power Syst., vol. 19, no. 1, pp. 260-266, 2004.

[29] Y. Baghzouz and S. Ertem, "Shunt capacitor sizing for radial distribution feeders with distorted substation voltages," IEEE Trans. Power Deliv., vol. 5, no. 2, pp. 650-657, 1990.

[30] M. E. Baran and F. F. Wu, "Network reconfiguration in distribution systems for loss reduction and load balancing," Power Deliv. IEEE Trans., vol. 4, no. 2, pp. 1401-1407, 1989.

[31] M. E. Baran and F. F. Wu, "Optimal capacitor placement on radial distribution systems.," IEEE Trans. Power Deliv., vol. 4, no. 1, pp. 725-734, 1989.

[32] D. Das, D. P. Kothari, and A. Kalam, "Simple and efficient method for load flow solution of radial distribution networks," Int. J. Electr. Power Energy Syst., vol. 17, no. 5, pp. 335-346, 1995.

[33] D. Zhang, Z. Fu, and L. Zhang, "An improved TS algorithm for loss-minimum reconfiguration in large-scale distribution systems," Electr. Power Syst. Res., vol. 77, no. 5-6, pp. 685-694, 2007.

[34] S. Sharma, S. Bhattacharjee, and A. Bhattacharya, "Quasi-Oppositional Swine Influenza Model Based Optimization with Quarantine for optimal allocation of DG in radial distribution network," Int. J. Electr. Power Energy Syst., vol. 74, pp. 348-373, 2016.

[35] B. Dogan and T. Olmez, "A new metaheuristic for numerical function optimization: Vortex Search algorithm," Inf. Sci. (Ny)., vol. 293, pp. 125-145, 2015. 